\title{
Regional evaluation of nutrient transformation and phytoplankton growth in nine river-dominated sub-tropical east Australian estuaries
}

\author{
Bradley D. Eyre* \\ Centre for Coastal Management, Southern Cross University, PO Box 157, Lismore, New South Wales 2480, Australia
}

\begin{abstract}
Nutrient transformation and phytoplankton growth were examined in 9 river-dominated sub-tropical east Australian estuaries in 1996 using modified mixing diagrams. The sampling program was rapid and strictly controlled, using 2 or 3 boats simultaneously, so that all 9 estuaries were usually sampled within 4 to $5 \mathrm{~d}$ of each other. River samples were collected at the head of each estuary on a flow-weighted basis, and variations in river concentrations and flushing times were used to calculate conservative mixing lines. This was to avoid 'apparent' non-linear distributions in the mixing diagrams associated with river-source variations on a time scale less or equal to the flushing time of the estuary. A number of general patterns of biogeochemical behaviour were observed across most, or all, of the estuaries. The 4 northern, and most likely the 5 southern, estuaries flushed fresh to the mouth during a flood in May, allowing most of the flood-borne material to escape from the system. Phytoplankton appear to exert the dominant control on nutrient transformation in the 9 estuaries, with non-biological processes only playing a minor role, if any. Eight of the 9 estuaries are potentially nutrient-limited, with nutrient concentrations falling below the upper half-saturation constants required for phytoplankton growth. The estuaries became potentially more P-limited, and less N-limited, as the wastewater loading to each system increased. During most sampling runs, maximum and mean concentrations of phytoplankton biomass (chlorophyll a) in the Tweed, Brunswick, Bellinger, Nambucca, Macleay and Hastings estuaries were significantly correlated with the wastewater DIN (dissolved inorganic nitrogen) loading index (daily wastewater load per $\mathrm{m}^{3}$ of estuary volume multiplied by the flushing time of the estuary in days). In contrast, the diffuse DIN loading index appeared more important for controlling phytoplankton biomass (chlorophyll a) in the 3 estuaries (Richmond, Clarence and Manning) that received a low wastewater DIN load. Sub-tropical Australian estuaries are characterised by a high degree of variability in nutrient delivery and phytoplankton growth. The timing and magnitude of hydrological factors appears to be the major feature that determines the differences in the temporal patterns of phytoplankton growth between sub-tropical and temperate regions. Nutrient-loading and phytoplankton growth in the 9 estuaries appears to be in phase, suggesting that stored and recycled nutrients may play a smaller role in maintaining phytoplankton growth in these systems compared to the larger partially mixed temperate systems. Management efforts in the 9 estuaries should be first directed towards reducing the wastewater DIN loading index to $<1$, followed by management strategies focused on controlling diffuse loadings. There may, however, be a trade-off associated with reducing the wastewater loading index with a proportional reduction in fisheries production.
\end{abstract}

KEY WORDS: Sub-tropical $\cdot$ Estuary $\cdot$ Comparison $\cdot$ Mixing plot $\cdot$ Nutrients $\cdot$ Phytoplankton growth Resale or republication not permitted without written consent of the publisher

\section{INTRODUCTION}

Global concern about nutrient (carbon, nitrogen, phosphorus) enrichment of estuaries and associated

*E-mail: beyre@scu.edu.au changes in their trophic status has seen considerable effort directed towards understanding how nutrients are transformed at the land-sea interface (Nixon 1995, Bricker \& Stevenson 1996). Nutrients are cycled between inorganic and organic forms and between pelagic and benthic compartments of estuaries by a

(c) Inter-Research 2000 
variety of biogeochemical processes. As such, detailed process-studies that measure rates of biogeochemical processes such as denitrification, $\mathrm{N}$-fixation, pelagic and benthic productivity, organic matter sedimentation and burial, pelagic and benthic respiration, and sediment-water fluxes are becoming commonplace in the literature. To describe a system fully, these rate measurements need to be undertaken as a package of measurements, at a variety of spatial and temporal scales, which unfortunately requires considerable technical expertise and logistical and financial support. Although this approach may be suitable for an intense research effort in 1 system (e.g. Chesapeake Bay: Smith et al. 1992, Kattegat: Jørgensen \& Richardson 1996, Port Phillip Bay: Harris et al. 1996, Moreton Bay: Dennison \& Abal 1999), it is beyond the capability and/or resources of most routine monitoring programs, particularly for regional evaluations of a number of systems.

Mixing diagrams (or property-salinity plots) provide a convenient method of displaying the net result of nutrient transformations at the land-sea interface, and interpretation of a number of different parameters displayed on mixing plots gives an indication of the likely biogeochemical processes occurring. For example, a set of mixing diagrams from the 1 survey in an estuary showing non-linear nitrate, ammonium and phosphate distributions indicated by a downward curvature in the mixing diagram combined with a corresponding upward curvature in chlorophyll, would suggest uptake of inorganic nutrients by phytoplankton. Applying an appropriate $\mathrm{C}: \mathrm{N}: \mathrm{P}$ ratio to the nutrient-removal curves also allows productivity rates to be approximated (e.g. Kaul \& Froelich 1984). In contrast, conservative mixing suggests that physical processes are operating at shorter time scales than the biogeochemical processes (Imberger et al. 1983). Most importantly, the data-collection programs necessary for the use of mixing diagrams are less intense than rate measurements, and therefore more suitable to routine monitoring programs.

The use of mixing diagrams was quite popular in the 1970s and 1980s (Boyle et al. 1974, Officer 1979, Fisher et al. 1988, Treguer \& Queguiner 1989, and many others), and although still seen in more recent literature (Balls 1994, Eyre \& Twigg 1997), their popularity has waned, probably due to criticism over steady-state assumptions. If the river concentration of a dissolved conservative parameter varies on a time scale less than or equal to the flushing time of the estuary, it may show an 'apparent' non-linear distribution on a mixing plot (Loder \& Reichard 1981, Officer \& Lynch 1981, Cifuentes et al. 1990). In Ochlockonee Bay, Florida, USA, for example, up to $10 \%$ of the nonconservative nutrient behaviour was due to variations in river concentrations (Kaul \& Froelich 1984). Even larger differ- ences (up to 4.6 times) between apparent and actual distributions of DIP were found in the Delaware Estuary (Lebo et al. 1994). However, if these variations in river concentrations and flushing times are included in the monitoring program, the use of mixing diagrams can be a valid, robust and convenient method suitable for the routine evaluation of nutrient transformations at the land-sea interface. This paper uses mixing diagrams with calculated conservative mixing lines, instead of the usual theoretical mixing lines, to evaluate nutrient transformations and phytoplankton growth at the land-sea interface of 9 river-dominated sub-tropical east Australian estuaries. Few studies of nutrient transformations and phytoplankton growth have been undertaken in river-dominated sub-tropical estuaries (Eyre 1997a, Eyre \& Twigg 1997, O'Donohue \& Dennison 1997, McKee et al. 2000), which are much more episodic and variable than typical temperate counterparts (Eyre 1998). This physical variability should be reflected in differences in the timing and magnitude of nutrient transformations and phytoplankton growth, and the factors controlling this transformation and growth, when compared to temperate systems.

\section{MATERIALS AND METHODS}

Study area. The 9 estuaries (Tweed, Brunswick, Richmond, Clarence, Bellinger, Nambucca, Macleay, Hastings and Manning) lie in a north-south band between 28.00 and $32^{\circ} 00^{\prime} \mathrm{S}$, in northern New South Wales (NSW) on the east coast of Australia (Fig. 1). The physical characteristics of each catchment and estuary are summarised in Table 1. The catchments range in size from $213 \mathrm{~km}^{2}$ (Brunswick), with river headwaters approx. $25 \mathrm{~km}$ inland draining coastal hills $(<500 \mathrm{~m}$ elevation), to $22446 \mathrm{~km}^{2}$ (Clarence), with river headwaters approx. $200 \mathrm{~km}$ inland draining the Main Divide (see Fig. 1). The estuaries experience a semidiurnal tidal cycle (typically 1 to $2 \mathrm{~m}$ ) and are generally shallow, averaging $\sim 2$ to $5 \mathrm{~m}$ in depth. This region experiences a wet and dry sub-tropical climate. During the summer months (October to April), moist, unstable, sub-tropical maritime airflows prevail, bringing heavy rainfalls and thunderstorms during wet years. During winter months (May to September), relatively stable anticyclonic air-pressure systems with clear skies and light winds dominate. The tropical influence decreases to the south, and winter rainfall of southern maritime origin may influence the southern catchments. Mean rainfall ranges from $\sim 1000 \mathrm{~mm}$ in the western parts of the catchments to $\sim 1800 \mathrm{~mm}$ on the coast.

Estuarine sampling program. Six sampling runs were undertaken in January, April/May, May, July/ August, September and December 1996. The sampling 


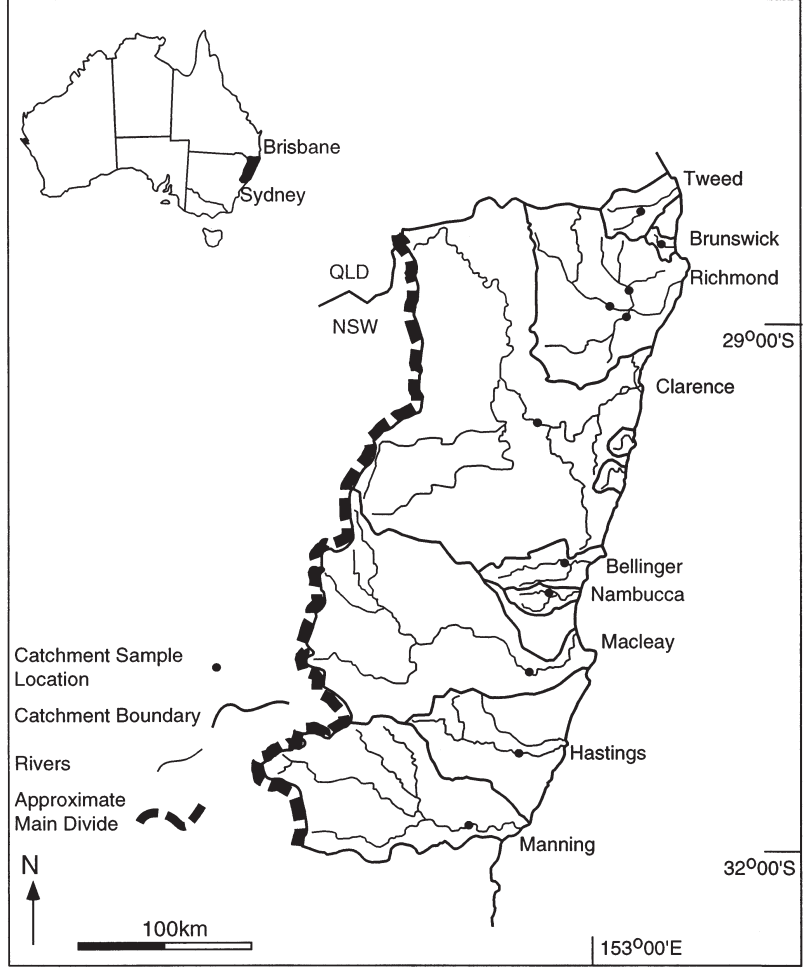

Fig. 1. Location of study area along east coast of Australia showing the 9 sub-tropical estuaries and catchment sample locations

program was rapid and strictly controlled, and used 2 or 3 boats simultaneously so that all 9 estuaries were usually sampled within 4 to $5 \mathrm{~d}$ of each other. Sampling runs were usually completed within $\sim 3$ to $4 \mathrm{~h}$, and were timed to start at the seawater end-member, $\sim 1 \mathrm{~h}$ before high tide, and progress landward with the high tide crest to the freshwater end-member. Samples were collected at intervals of approx. 2 on the practical salinity scale, from seawater to freshwater along the axial salinity gradient in the estuary. An additional sampling run was undertaken during a flood peak on 5 to 7 May. However, the 5 southern estuaries were not accessible because of rising flood waters, and samples were only collected from the mouths of the 4 northern estuarine basins, as there was no salinity gradient since they were flushed fresh to the mouth.

Two sample-collection strategies were employed, depending on the water-column stratification. When the water column was highly stratified, surface samples (top $30 \mathrm{~cm}$ ) were collected using an acid-washed and sample-rinsed bucket (being careful not to collect the surface scum), and when the water column was well-mixed, samples were collected from a depth of $1.5 \mathrm{~m}$ by hand-pumping water to the surface. Every 10th sample was collected in triplicate for quality control. Samples were filtered immediately through $0.45 \mu \mathrm{m}$ cellulose acetate membrane filters (Sartorius) into acid-washed and sample-rinsed polyethylene vials. At each sample location, 500 to $2000 \mathrm{ml}$ of water (dependent on suspended-sediment load) was filtered through glass-fibre filters (Whatman) for chlorophyll analysis. Each filter was placed into an acid-washed $10 \mathrm{ml}$ polyethylene vial and wrapped in aluminum foil. An unfiltered sample was collected in an acid-washed and sample-rinsed polyethylene vial for total nutrient analysis. A $250 \mathrm{ml}$ sample was collected in a samplerinsed polyethylene bottle for total suspended-sediment analysis. All nutrient and chlorophyll samples were frozen immediately in the dark on dry ice.

Physico-chemical parameters (salinity/conductivity, dissolved oxygen, temperature, turbidity) were measured in situ at the point of sampling using a Horiba U10 multiprobe. Salinity profiles were also undertaken at each sample location. Conductivity was calibrated against $0.005,0.05$, and $0.5 \mathrm{M}$ standard potassium

Table 1. Catchment and estuary characteristics for the 9 sub-tropical systems studied (Catchment land use $=\%$ forest + natural vegetation)

\begin{tabular}{|c|c|c|c|c|c|c|c|c|c|}
\hline \multirow[t]{2}{*}{ Catchment } & \multirow[b]{2}{*}{$\begin{array}{c}\text { Catchment } \\
\text { area } \\
\left(\mathrm{km}^{2}\right)\end{array}$} & \multirow[b]{2}{*}{$\begin{array}{l}\text { Mean } \\
\text { annual } \\
\text { rainfall } \\
(\mathrm{mm})\end{array}$} & \multirow{2}{*}{$\begin{array}{l}\text { - Hydrology } \\
\text { Mean } \\
\text { runoff } \\
\text { coefficient }\end{array}$} & \multirow[b]{2}{*}{$\begin{array}{c}\text { Mean } \\
\text { annual } \\
\text { runoff } \\
(\mathrm{mm})\end{array}$} & \multirow[b]{2}{*}{$\begin{array}{l}\text { Length } \\
(\mathrm{km})\end{array}$} & \multicolumn{3}{|c|}{ Estuary characteristics } & \multirow{2}{*}{$\begin{array}{l}\text { Catchment } \\
\text { land use }\end{array}$} \\
\hline & & & & & & $\begin{array}{l}\text { Area } \\
\left(\mathrm{km}^{2}\right)\end{array}$ & $\begin{array}{c}\text { Mean } \\
\text { depth } \\
(\mathrm{m})\end{array}$ & $\begin{array}{c}\text { Vol. } \\
\left(\mathrm{m}^{3} \times 10^{6}\right)\end{array}$ & \\
\hline Tweed & 1068 & 1716 & 0.29 & 498 & 33 & 7.1 & 3.0 & 21.3 & 30 \\
\hline Brunswick & 213 & 1777 & 0.30 & 533 & 11 & 1.3 & 2.5 & 3.3 & 10 \\
\hline Richmond & 6861 & 1849 & 0.23 & 425 & 41 & 14.3 & 4.7 & 67.7 & 41 \\
\hline Clarence & 22446 & 1075 & 0.20 & 215 & 62 & 89.0 & 2.3 & 204.7 & 55 \\
\hline Bellinger & 1128 & 1471 & 0.26 & 382 & 17 & 2.1 & 2.2 & 4.6 & 54 \\
\hline Nambucca & 1326 & 1354 & 0.25 & 339 & 29 & 4.2 & 2.5 & 10.5 & 25 \\
\hline Hastings & 10686 & 1217 & 0.26 & 316 & 30 & 7.9 & 3.3 & 26.1 & 48 \\
\hline Macleay & 3715 & 1310 & 0.14 & 183 & 30 & 7.6 & 4.1 & 31.2 & 55 \\
\hline Manning & 8195 & 1276 & 0.26 & 332 & 41 & 15.4 & 4.8 & 73.9 & 76 \\
\hline
\end{tabular}


chloride solutions. $\mathrm{pH}$ was calibrated with standard buffer solutions at $\mathrm{pH} 4$ and 7. Dissolved oxygen was calibrated against a zero oxygen solution (sodium sulfide) and an air-saturated beaker of water checked with Winkler titration. The Horiba U-10 calibration was checked at the end of each sampling run and never exceeded $\pm 2.5 \%$ of the correct standard value for any of the calibrated parameters. As such, no corrections for instrument drift have been made.

River sampling program. Samples were collected by volunteers from just above the estuarine bay line of all 9 estuaries (Fig. 1) on a flow-weighted basis (up to 6 times daily during high-flow events, fortnightly during base flow) from December 1995 to December 1996. Surface samples were collected mid-channel (where possible) using an acid-washed and sample-rinsed 11 polyethylene bottle (being careful not to collect the surface scum), and filtered immediately through $0.45 \mu \mathrm{m}$ cellulose acetate membrane filters (Sartorius) into acid-washed and sample-rinsed polyethylene vials. An unfiltered sample was collected in an acidwashed and sample-rinsed polyethylene vial for total nutrient analysis. A $250 \mathrm{ml}$ sample was collected in a sample-rinsed polyethylene bottle for total suspendedsediment analysis. All nutrient samples were stored on ice, in the dark, and frozen $\left(-20^{\circ} \mathrm{C}\right)$ within $1 \mathrm{~h}$.

Analytical techniques. Nutrient forms analysed, abbreviations, analytical procedures and errors are summarised in Table 2. All nutrient analyses were carried out colorimetrically using Lachat ${ }^{\mathrm{TM}}$ flow-injection analysis. Approximately every 10th sample was analysed in triplicate, and analytical errors were determined as the average \% coefficient of variation, $\mathrm{CV}$, of the triplicates. Because the variance of the analytical procedures propagates additively, the variance associated with the nutrient forms calculated by difference was estimated as the sum of the variances of the 2 measured nutrient forms used in the calculation (Eyre 1995). Analytical accuracy was maintained using standard additions of certified laboratory standards in both Milli-Q and low-nutrient seawater.

Conservative mixing lines. A simple mixing model was used to predict nutrient distributions in the estuary that result from the mixing of river water with seawater for each of the measured surveys (i.e. conservative mixing line). Measured cross-sections and volumes of each estuary, actual salinity distributions during each survey, daily river discharges and measured (or estimated by linear interpolation) daily river-nutrient concentrations and measured seawater-nutrient concentrations were used in the model. The predicted concentration $\left(C_{\mathrm{x}}\right)$ at any given salinity, at the time of the survey of interest, can be calculated by:

$$
C_{\mathrm{x}}=\left(1-S_{\mathrm{x}} / S_{\mathrm{s}}\right) \times C_{\mathrm{r}}+\left(S_{\mathrm{x}} / S_{\mathrm{s}}\right) \times C_{\mathrm{s}}
$$

where $S_{\mathrm{x}}$ is the seawater salinity, $S_{\mathrm{s}}$ is the salinity of interest, $C_{\mathrm{s}}$ is the seawater concentration and $C_{\mathrm{r}}$ is the river concentration $i$ days before the survey, where:

$$
i=X / L \times V / Q \times\left(1-S_{\mathrm{avg}} / S_{\mathrm{s}}\right)
$$

where $X$ is the distance from the mouth of the non-tidal river to the salinity of interest, $L$ is the total length of the estuary, $V$ is the volume of the estuary, $Q$ is the daily river discharge averaged over $i$ days before the given time (by trial and error), and $S_{\text {avg }}$ is the average salinity of the estuary. $Q$ was estimated by correcting upstream-gauged discharges (Water Resources Com-

\begin{tabular}{|c|c|c|c|c|c|}
\hline Nutrient form & Abbreviation & Method & $\begin{array}{l}\text { Detection } \\
\text { limit }\end{array}$ & $\begin{array}{c}\text { Error } \\
(\%)\end{array}$ & Source \\
\hline Total phosphorus & TP & Persulfate digestion & $0.30 \mu \mathrm{M}$ & 3.8 & Valderrama (1981) \\
\hline Particulate phosphorus & PP & TP - TDP & & 6.3 & \\
\hline Total dissolved phosphorus & TDP & Persulfate digestion & $0.16 \mu \mathrm{M}$ & 3.5 & Valderrama (1981) \\
\hline Dissolved inorganic phosphorus & DIP & Ascorbic acid & $0.003 \mu \mathrm{M}$ & 2.3 & Lachat (1994) \\
\hline Dissolved organic phosphorus & DOP & TDP - DIP & & 5.1 & \\
\hline Total nitrogen & $\mathrm{TN}$ & Persulfate digestion & $0.07 \mu \mathrm{M}$ & 4.3 & Valderrama (1981) \\
\hline Particulate nitrogen & PN & TN - TDN & & 7.3 & \\
\hline Total dissolved nitrogen & TDN & Persulfate digestion & $0.7 \mu \mathrm{M}$ & 4.1 & Valderrama (1981) \\
\hline Dissolved organic nitrogen & DON & $\mathrm{TDN}-\left(\mathrm{NO}_{2}^{-}+\mathrm{NO}_{3}^{-}+\mathrm{NH}_{4}^{+}\right)$ & & 19.6 & \\
\hline Nitrite & $\mathrm{NO}_{2}^{-}$ & Sulphanilamide & $0.07 \mu \mathrm{M}$ & 2.8 & Lachat (1994) \\
\hline Nitrate & $\mathrm{NO}_{3}{ }^{-}$ & $\mathrm{NO}_{\mathrm{x}}-\mathrm{NO}_{2}^{-}$ & $0.07 \mu \mathrm{M}$ & 5.6 & Lachat (1994) \\
\hline Oxidised nitrogen & $\mathrm{NO}_{\mathrm{x}}$ & Cadmium reduction & & 3.6 & \\
\hline Ammonium & $\mathrm{NH}_{4}{ }^{+}$ & Hypochlorite/phenolate & $0.35 \mu \mathrm{M}$ & 5.1 & Lachat (1994) \\
\hline Dissolved inorganic nitrogen & DIN & $\left(\mathrm{NO}_{2}^{-}+\mathrm{NO}_{3}^{-}+\mathrm{NH}_{4}^{+}\right)$ & & 7.2 & \\
\hline Silicate & Silicate & Molyosilicate/oxalic acid & $0.17 \mu \mathrm{M}$ & 3.4 & Lachat (1994) \\
\hline Total suspended sediments & TSS & Gravimetric & & & Strickland \& Parsons (1972) \\
\hline Chlorophyll a & Chl a & Acetone extraction & & 4.1 & Strickland \& Parsons (1972) \\
\hline
\end{tabular}

Table 2. Nutrient forms, abbreviations, analytical procedures, detection limits, and analytical errors 
mission, Armidale) by linear extrapolation to account for the ungauged areas of the catchment. $V$ were calculated from between $\sim 15$ and 30 echo-sounding profiles (cross-sections) at $\sim 500$ to $3000 \mathrm{~m}$ intervals, depending on the length of the estuary and the homogeneity of the estuarine sections. $S_{\text {avg }}$ was calculated from $\sim 10$ to 20 vertical salinity profiles taken at 500 and $3000 \mathrm{~m}$ intervals along the axis of each system during each survey. Predicted concentrations were calculated for each of the salinities at which samples were collected for the survey of interest, and a 4th-order polynomial was fitted to the predicted distributions to obtain the conservative mixing line.

Freshwater flushing times. Freshwater flushing times during each survey were calculated using the fraction of freshwater method (Kennish 1986). The flushing time is defined as the time required to replace the existing freshwater in the estuary at a rate equal to the river discharge. However, instead of using the precedings day's discharge, the freshwater replacement time was calculated by summing the daily discharges prior to the sampling date until the volume of freshwater in the estuary was equalled (Kaul \& Froelich 1984).

Load calculations. Diffuse loadings to each estuary were calculated by integrating the product of flowweighted concentrations and daily flows. River discharge was estimated by correcting upstream-gauged discharges (Department of Land and Water Conservation, Armidale) by an area coefficient to account for the ungauged areas of the catchment. The hydrograph response of floods in the catchments typically spans several days, as such daily sampling during floods with samples collected on rising and falling stages is considered sufficient to characterise loads. Fortnightly to monthly samples were collected during base-flow conditions.

Daily wastewater nutrient-loadings were calculated for the wastewater treatment plants that discharge into each estuary by dividing annual wastewater loads by 365 (days in a year). The total annual wastewater loads for the NSW estuaries had been previously estimated by Manly Hydraulics Laboratory (MHL), Sydney, as part of a review of estuarine sewage outfalls in NSW (P. Anderson pers. comm.). DIN and DIP loads were estimated by assuming that $75 \%$ of the TN and TP loads consisted of dissolved inorganic forms. This percentage was derived from a more detailed analysis of wastewater loads discharged into the Brunswick Estuary (Eyre 1997b).

Statistical analysis. Correlations between waterquality parameters were analysed using a Pearson's, correlation matrix (2-tailed test) undertaken using SPSS 7.0 software. Data normality was assessed using a Kolmogorov-Smirnov goodness of fit test. Further details of the statistical methods and software used can be found in Norusis (1994).

\section{RESULTS}

\section{Hydrology}

Three major flow events occurred in all 9 catchments during the 1996 study period (Fig. 2). The large narrow hydrograph peaks separated by low base-flow illustrate the episodic nature of the 9 systems. In the 5 northern catchments, a small first-flush event occurred in January, followed by a large 10 to 20 yr returnperiod flood in early May, and a minor event in late November. A similar large flood event occurred in May in the 4 southern catchments. However, in contrast to the northern catchments, the January and late November events were also of a similar size. Run 1 was timed to capture the effect of the January first flush, with the estuary sampling being undertaken on the falling limb of the hydrograph. Run 2 was taken immediately before the May flood, at the end of a 3 mo dry period that had lasted since the January event. Run 3 was undertaken as the estuary recovered following the May flood. Run 4 was undertaken following a small runoff event in July, Run 5 during the dry season when little or no change in freshwater discharge occurred, and Run 6 following a small late-November flow event.

\section{Salinity structure and flushing characteristics}

Salinity profiles obtained during 1996 show a full spectrum of mixing regimes from highly stratified to well mixed in each of the 9 estuaries (B.D.E. unpubl. data). During Run 1, the 9 estuaries were stratified following the January runoff event, and saltwater only intruded part of the way along the estuarine basins. By Run 2, the estuaries were well mixed and brackishwater intruded the full length of the estuarine basins. On 5 to 7 May, the 4 northern estuaries, and most likely the 5 southern estuaries, were flushed fresh to the mouth. About 3 wk later, during Run 3, a prominent salt-wedge structure had penetrated landward along the channel bottom of the 9 estuaries, developing a sharply defined halocline at $\sim 1$ to $2 \mathrm{~m}$. By Run 4 , salt water had intruded through most of the full length of the estuarine basin, but all the estuaries were still slightly stratified due to the small runoff event in July. As river flow decreased during Runs 5 and 6 (dry season), salt water intruded to its maximum extent upstream, and the estuaries returned to their normal well-mixed state, although the southern estuaries were partially mixed due to a runoff event in late November (Fig. 2). The rate at which the 9 estuaries recover following floods is partially related to freshwater discharge and estuary volume. There was a weak, but significant, relationship $\left(\mathrm{r}^{2}=0.43 ; \mathrm{p}<0.001\right)$ between 


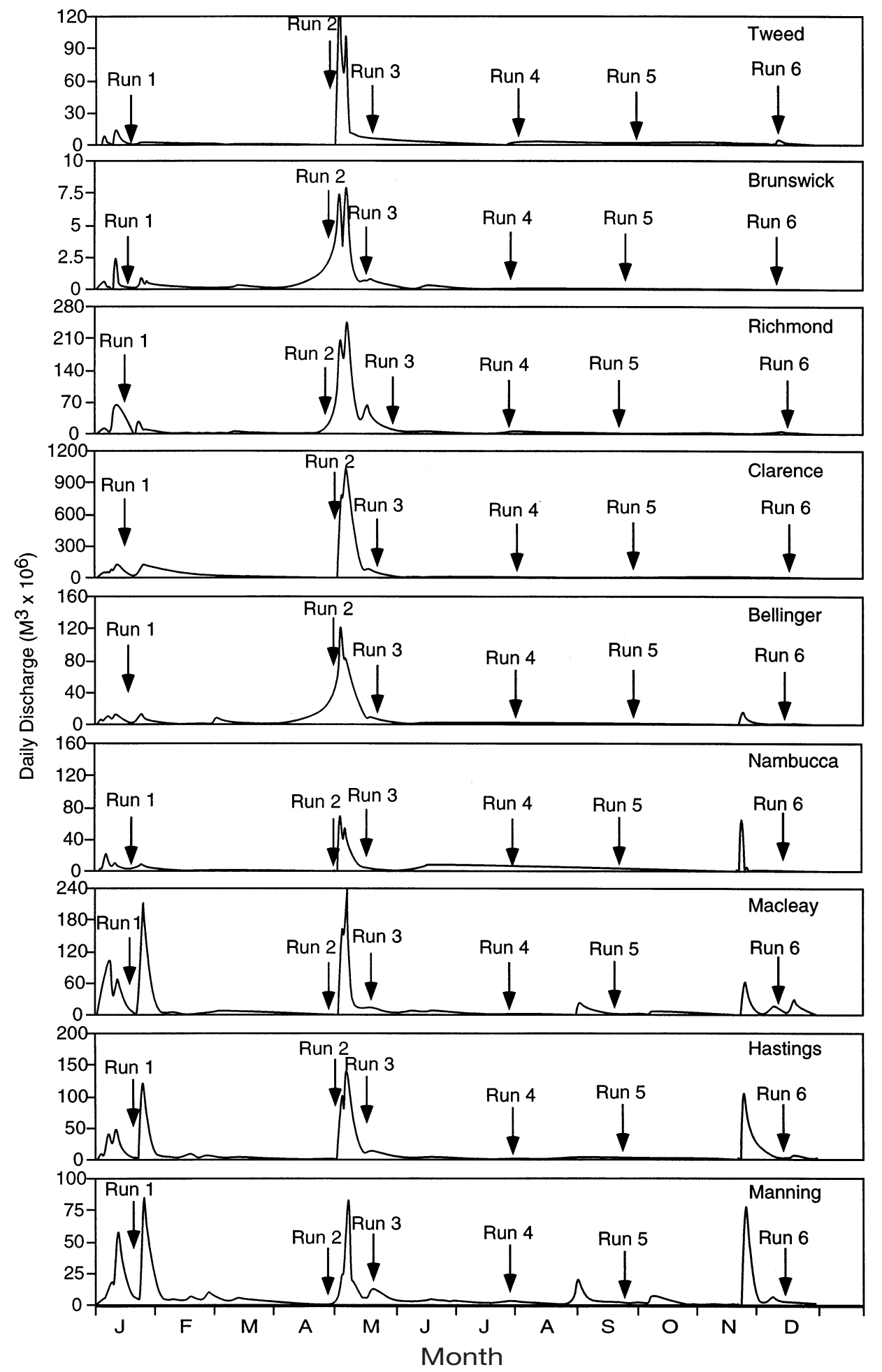

Fig. 2. Hydrographs for the 9 sub-tropical estuaries during the study period, showing timing of sample-collection runs

freshwater discharge divided by the estuary volume and the percentage length of the estuarine basin along which the salt water-freshwater interface had intruded.
Freshwater flushing times were variable, reflecting freshwater discharge. The longest flushing times occurred during Runs 2 and 5, the shortest during Run 3 following the May flood (Table 3). Overall, the 
Table 3. Flushing times (d) for each run for each of the 9 sub-tropical estuaries. Average flushing time for each run and for each estuary is also shown

\begin{tabular}{|c|c|c|c|c|c|c|c|}
\hline & Run 1 & Run 2 & Run 3 & Run 4 & Run 5 & Run 6 & Average \\
\hline Tweed & 10.1 & 14.7 & 7.1 & 18.6 & 53.1 & 15.7 & 22.4 \\
\hline Brunswick & 4.7 & 17.4 & 1.8 & 6.6 & 35.3 & 9.3 & 14.7 \\
\hline Richmond & 8.4 & 23.6 & 6.1 & 5.5 & 36.2 & 6.7 & 16.1 \\
\hline Clarence & 12.4 & 66.4 & 2.0 & 24.5 & 47.4 & 23.8 & 34.9 \\
\hline Bellinger & 1.3 & 2.6 & 1.0 & 5.3 & 6.8 & 8.0 & 4.8 \\
\hline Nambucca & 2.1 & 4.1 & 1.6 & 8.4 & 10.7 & 12.6 & 7.6 \\
\hline Macleay & 3.7 & 23.1 & 2.0 & 9.4 & 13.6 & 2.5 & 10.5 \\
\hline Hastings & 2.3 & 7.2 & 2.0 & 5.4 & 10.6 & 3.2 & 5.8 \\
\hline Manning & 8.3 & 26.4 & 1.1 & 24.0 & 8.3 & 10.6 & 15.5 \\
\hline Average & 5.9 & 20.6 & 2.7 & 12.0 & 24.7 & 10.3 & \\
\hline
\end{tabular}

Bellinger Estuary was the most rapidly flushed of the 9 estuaries, and the Clarence Estuary had the longest flushing times. However, these flushing times cannot be considered typical. The high inter-annual variation in flushing times for these sub-tropical estuaries is illustrated by comparing the 1996 flushing times in the Richmond (Table 3) with 1994 and 1995 flushing times, which ranged from 0 to 196 and 0 to 176 d (Eyre \& Twigg 1997, Hossain 1997). Clearly, the intra-annual variability in flushing times was also higher during 1994. Most of the variability in flushing times can be explained by freshwater discharge and estuary volume. There was a strong and significant relationship $\left(\mathrm{r}^{2}=0.79 ; \mathrm{p}<0.001\right)$ between freshwater discharge divided by the estuary volume and flushing times for the 9 estuaries (Fig. 3).

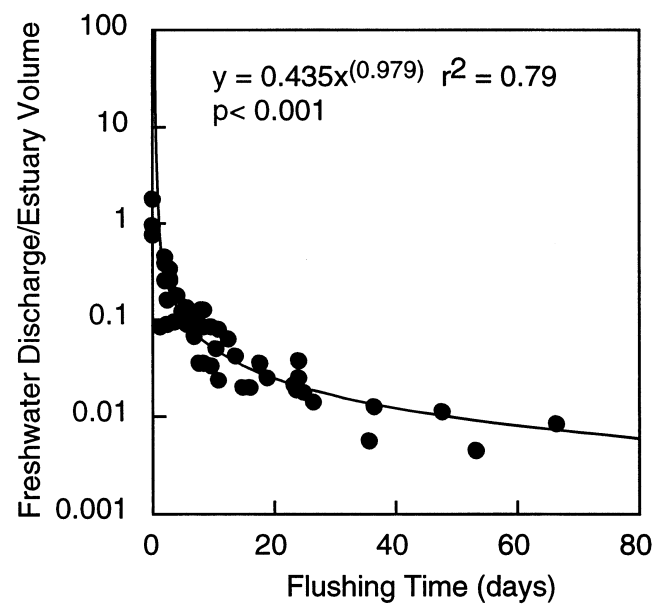

Fig. 3. Flushing times for each run for each estuary as a function of freshwater discharges for each catchment divided by estuary volume

\section{Total suspended sediments}

Total suspended sediment (TSS) concentrations in all 9 estuaries for all runs ranged from 0.2 to $40.0 \mathrm{mg} \mathrm{l}^{-1}$, with a median of $4.0 \mathrm{mg} \mathrm{l}^{-1}$, a mean of $5.5 \mathrm{mg} \mathrm{l}^{-1}$, and a standard deviation of $5.2 \mathrm{mg} \mathrm{l}^{-1}(\mathrm{n}=928)$ (Figs. 4 to 9). Much higher TSS concentrations of 60, 25, 256 and $206 \mathrm{mg} \mathrm{l}^{-1}$ were measured at the mouths of the Tweed, Brunswick, Richmond and Clarence estuaries respectively during the flood peak on the 5 to 7 May 1996. However, these elevated concentrations decreased rapidly and were similar to pre-flood concentrations (Run 2) by the time the postflood sampling run (Run 3) was undertaken approx. 2 to 3 wk later. TSS concentrations are positively correlated with TN concentrations $(\mathrm{r}=+0.51 ; \mathrm{p}<0.001)$, suggesting a similar source. Following flood events (i.e. Runs 1 and $3)$, TSS concentrations were generally higher at the freshwater end-member and decreased towards the seawater end-member. In nearly all cases, this decrease was either linear, with TSS concentrations falling along the actual mixing line, or concave downwards, with TSS concentrations falling below the actual mixing line. Only the Richmond and Macleay estuaries had TSS concentrations falling along the actual mixing line for both Runs 1 and 3, indicating that all the remaining estuaries trap a proportion of their post-flood catchment suspended-sediment load. During the dry season (Runs 2, 4 and 5), the estuaries showed a range of behaviours, with TSS concentrations above the actual mixing lines, suggesting tidal or wind resuspension. Tidal and wind resuspension appears to have been most prevalent during Run 5, when the Tweed, Brunswick, Richmond, Nambucca and Macleay estuaries all had TSS concentrations above the actual mixing lines. None of the estuaries showed persistent features, such as turbidity maxima, that are commonly seen in other systems (e.g. Fisher et al. 1988, Balls 1994), which reflects their well-mixed salinity structure throughout most of the year. 


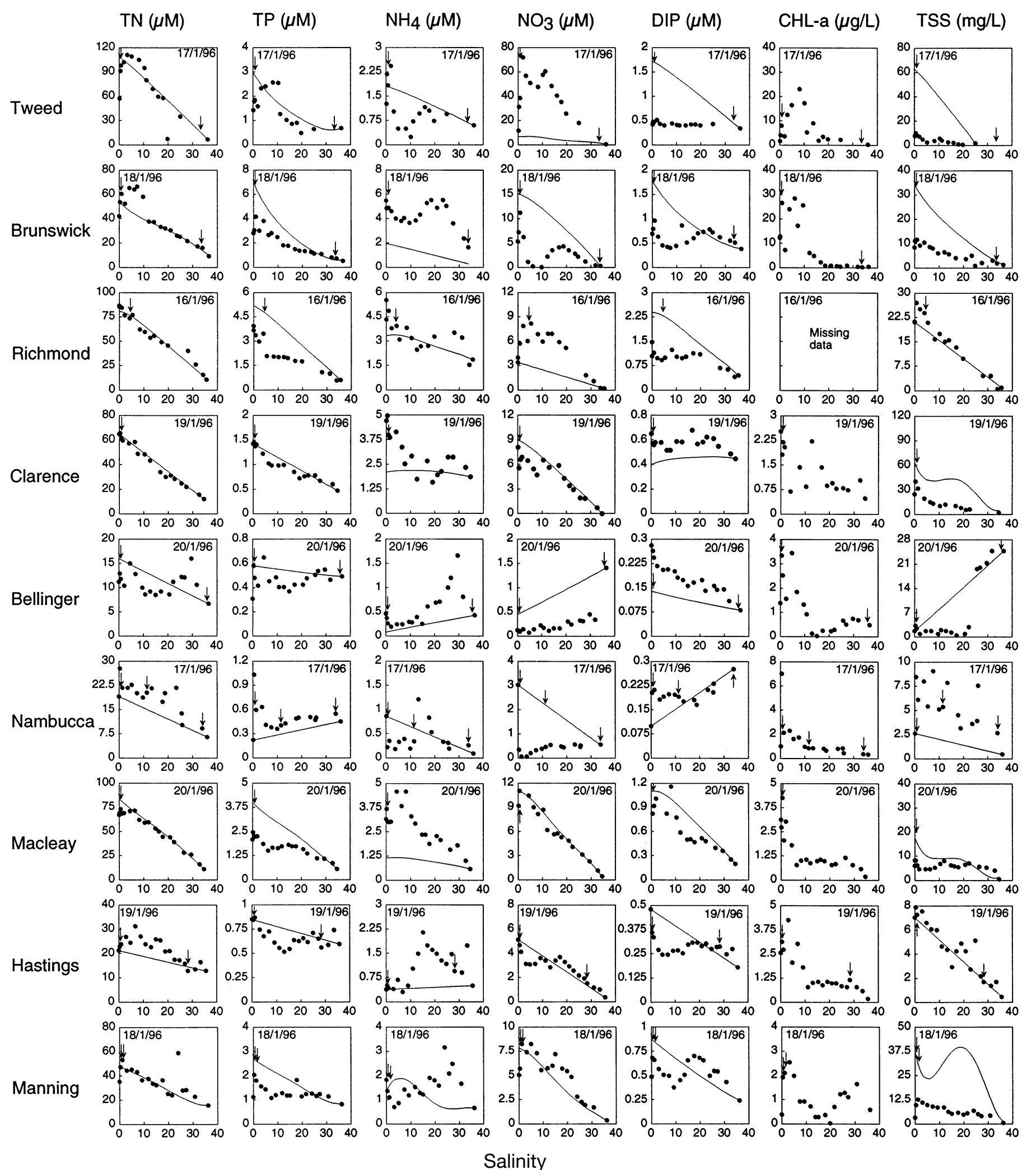

Fig. 4. Run 1. Total nitrogen (TN), total phosphorus (TP), ammonium $\left(\mathrm{NH}_{4}{ }^{+}\right)$, nitrate $\left(\mathrm{NO}_{3}{ }^{-}\right)$, dissolved inorganic phosphorus (DIP), chlorophyll a (CHL-a), and total suspended sediments (TSS) in the 9 sub-tropical estuaries, plotted as a function of salinity for Run 1. Arrows show location of wastewater-treatment plants. Date $(\mathrm{d} / \mathrm{mo} / \mathrm{yr})$ is shown in each graph 
$\mathrm{TN}(\mu \mathrm{M})$

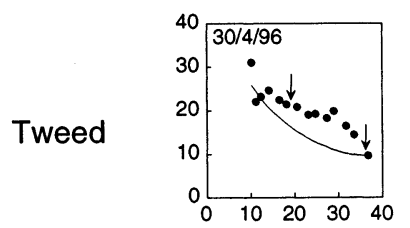

Tweed

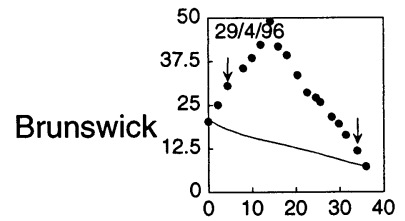

Richmond
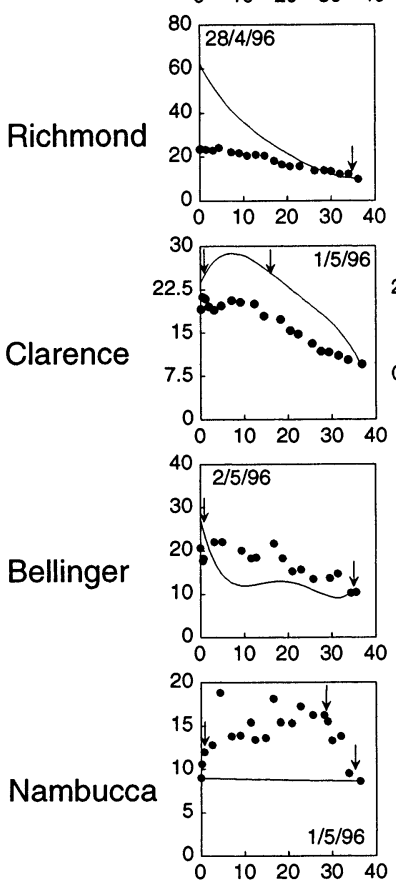

Macleay
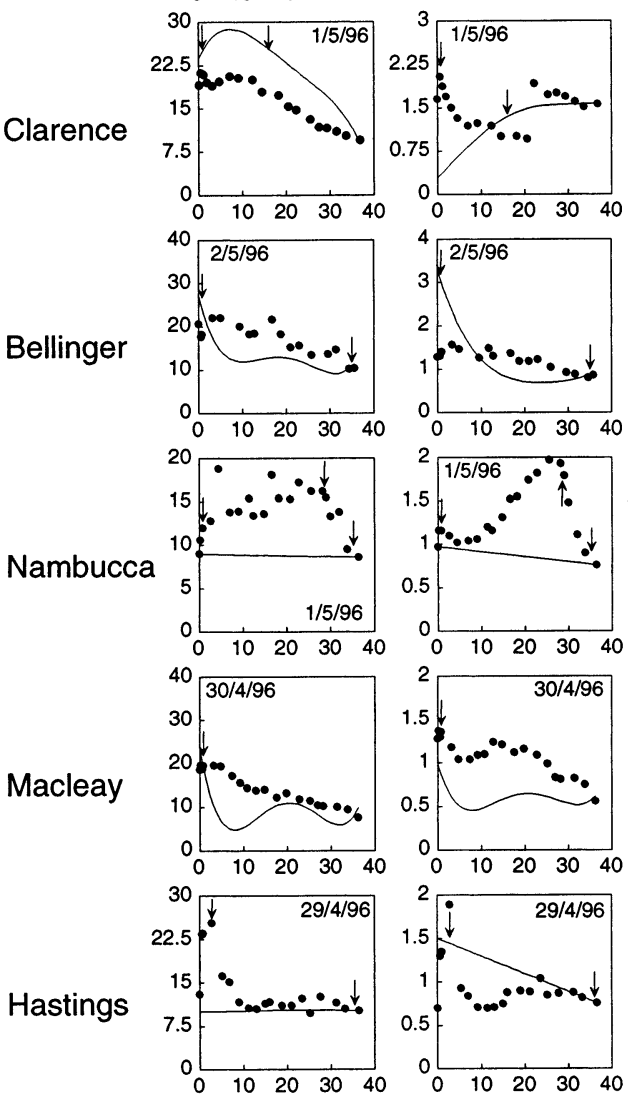

Manning

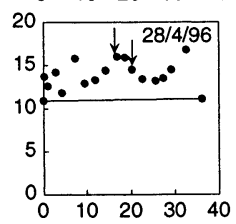

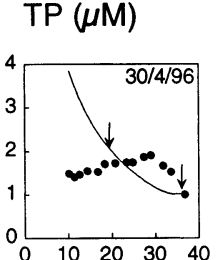
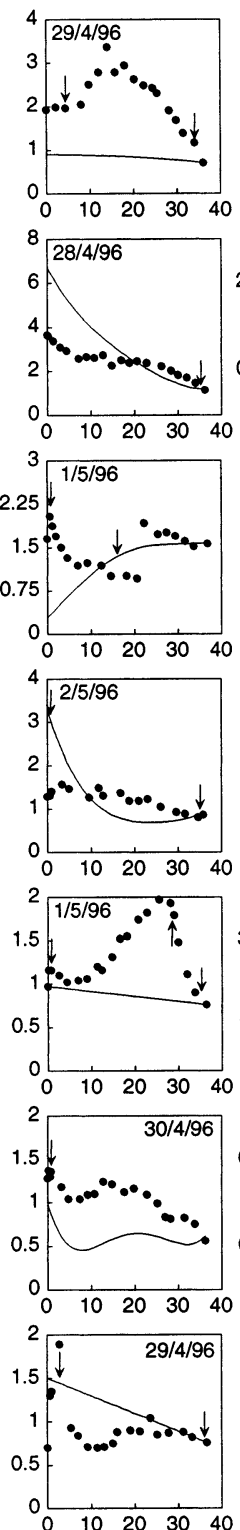

$\mathrm{NH}_{4}(\mu \mathrm{M})$
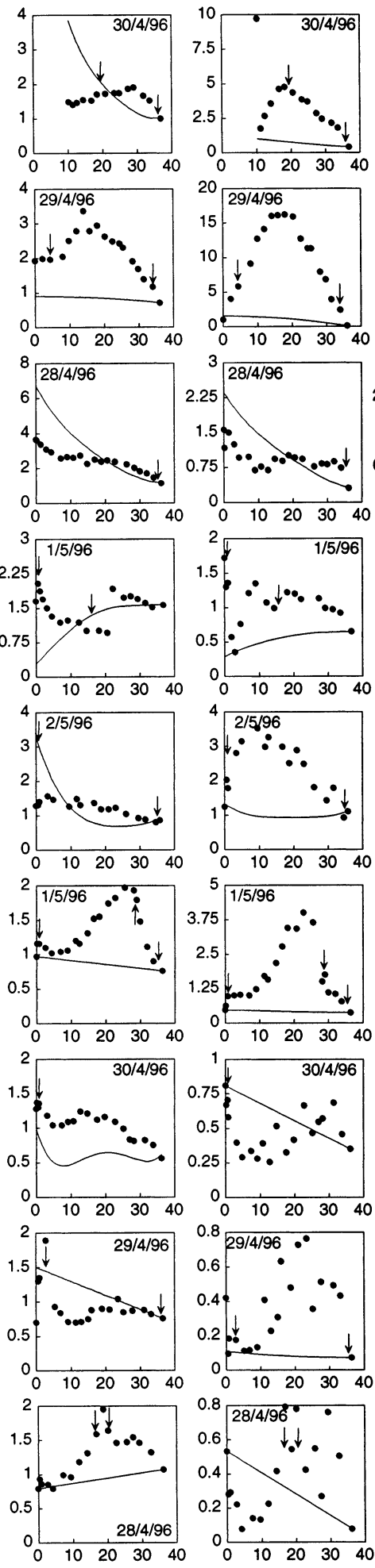

$\mathrm{NO}_{3}(\mu \mathrm{M})$

DIP $(\mu \mathrm{M})$
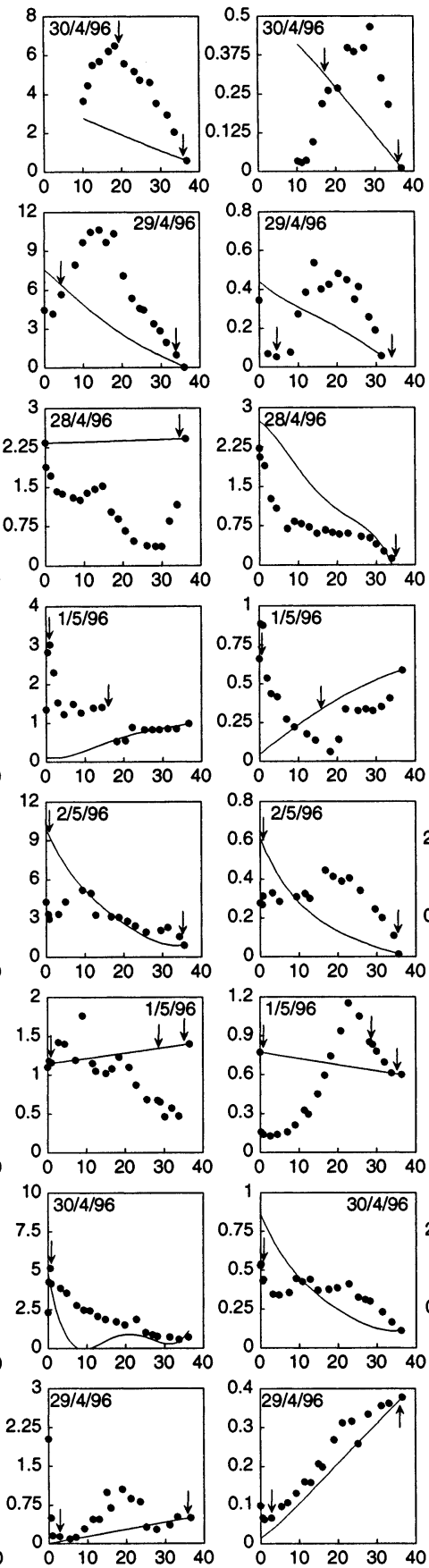
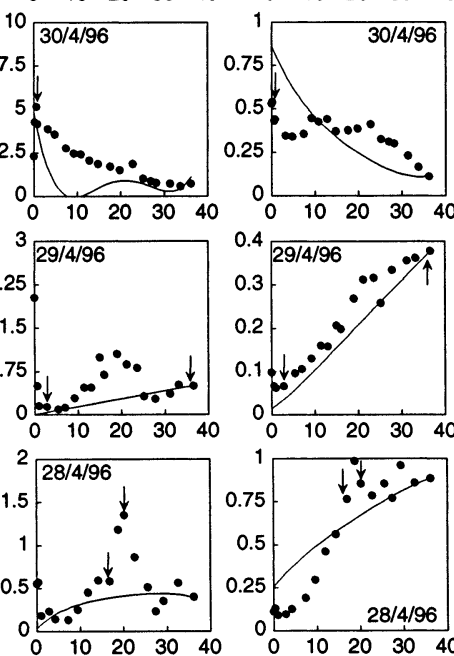

$\mathrm{CHL}-\mathrm{a}(\mu \mathrm{g} / \mathrm{L})$

TSS (mg/L)
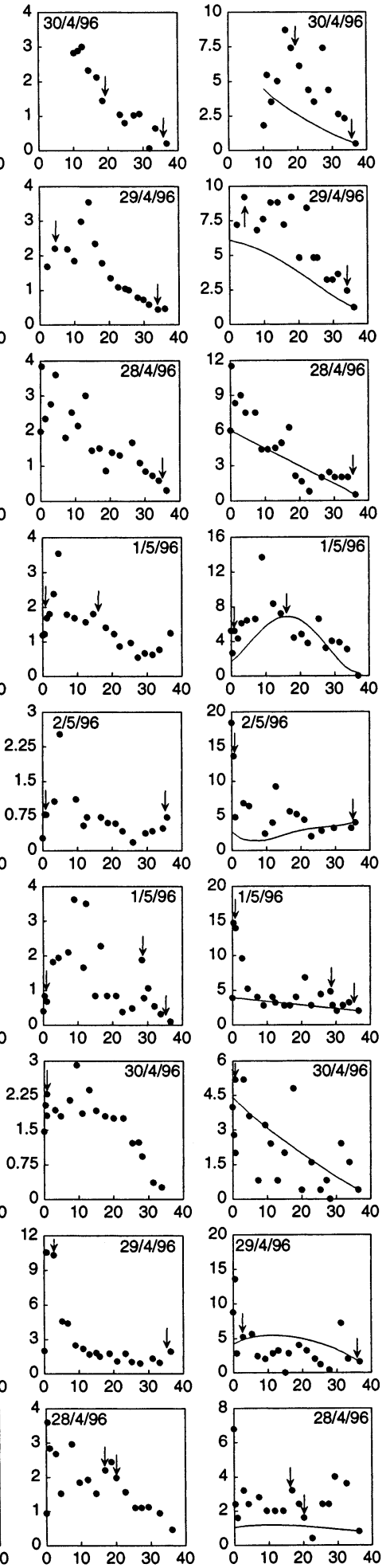

Salinity

Fig. 5. Run 2. Total nitrogen (TN), total phosphorus (TP), ammonium $\left(\mathrm{NH}_{4}{ }^{+}\right)$, nitrate $\left(\mathrm{NO}_{3}{ }^{-}\right)$, dissolved inorganic phosphorus (DIP), chlorophyll a (CHL-a), and total suspended sediments (TSS) in the 9 sub-tropical estuaries, plotted as a function of salinity for Run 1. Arrows show location of wastewater-treatment plants. Date $(\mathrm{d} / \mathrm{mo} / \mathrm{yr})$ is shown in each graph 
Tweed

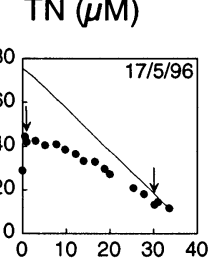

$\operatorname{TP}(\mu \mathrm{M})$
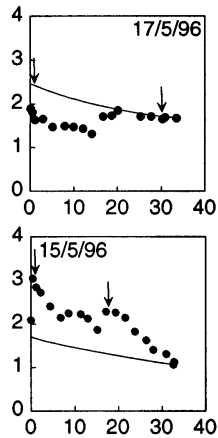

Brunswick
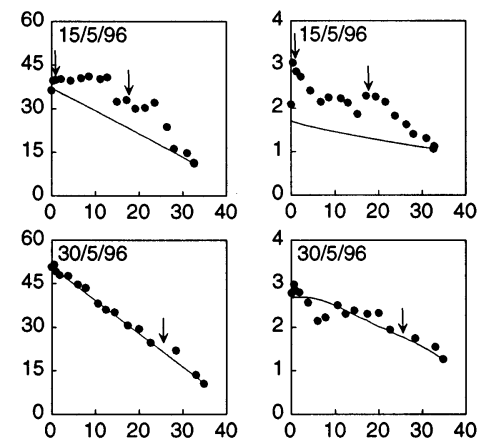

Richmond
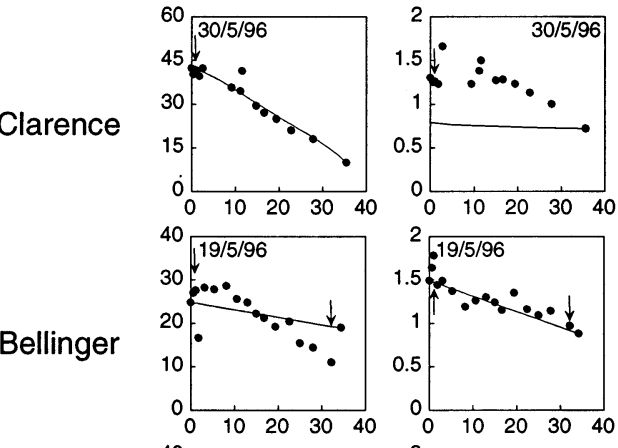

Bellinger

Nambucca
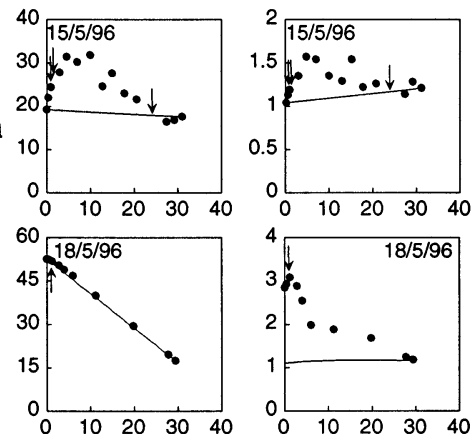

Macleay
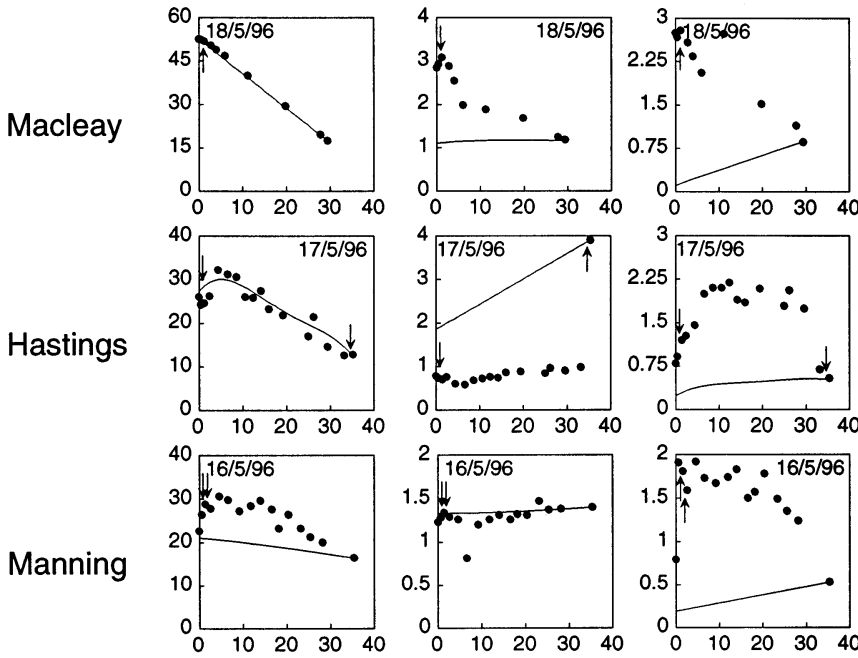

$\begin{array}{llllll}0 & 10 & 20 & 30 & 40\end{array}$

\section{$\mathrm{NH}_{4}(\mu \mathrm{M})$}
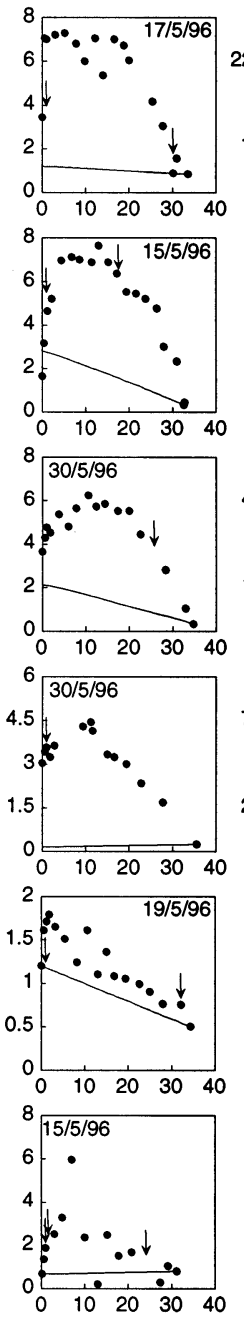

$\mathrm{NO} 3(\mu \mathrm{M})$
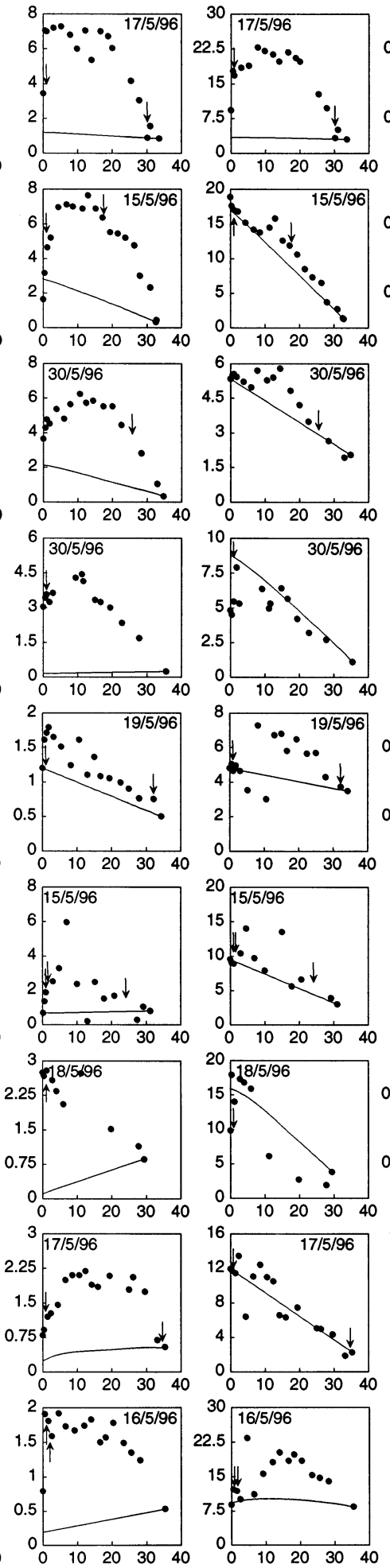

$\operatorname{DIP}(\mu \mathrm{M})$

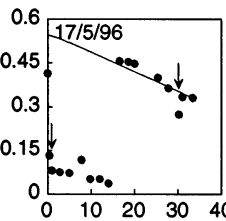

CHL-a $(\mu g / L)$

TSS (mg/L)
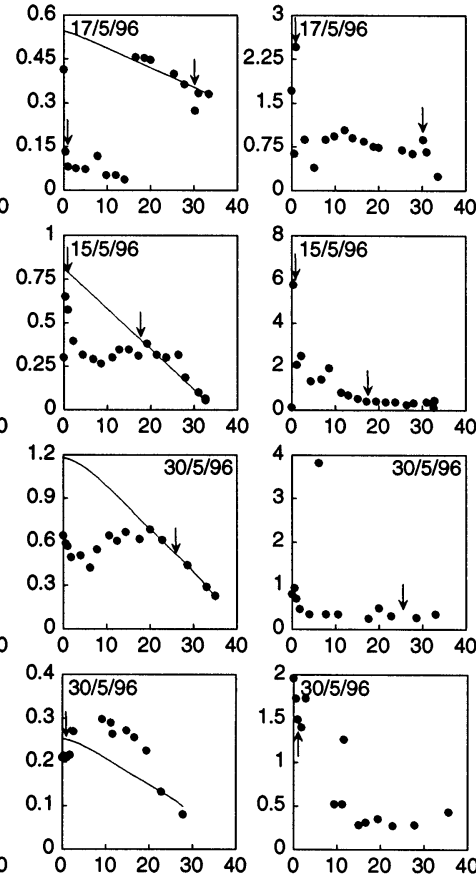

2
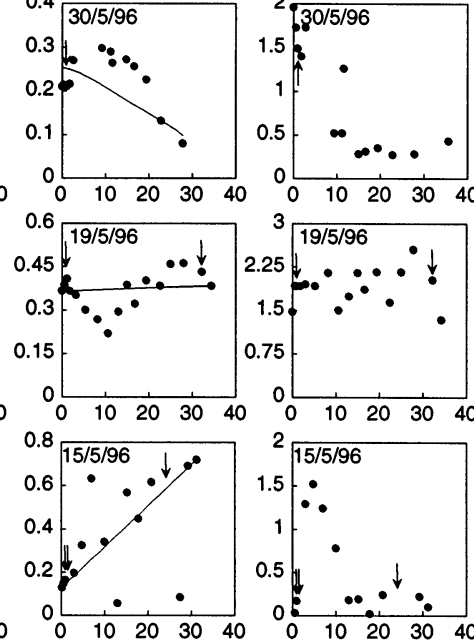

$2 \longdiv { 1 5 / 5 / 9 6 }$

1.5

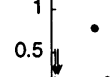

$0.5 \cdot \cdots$
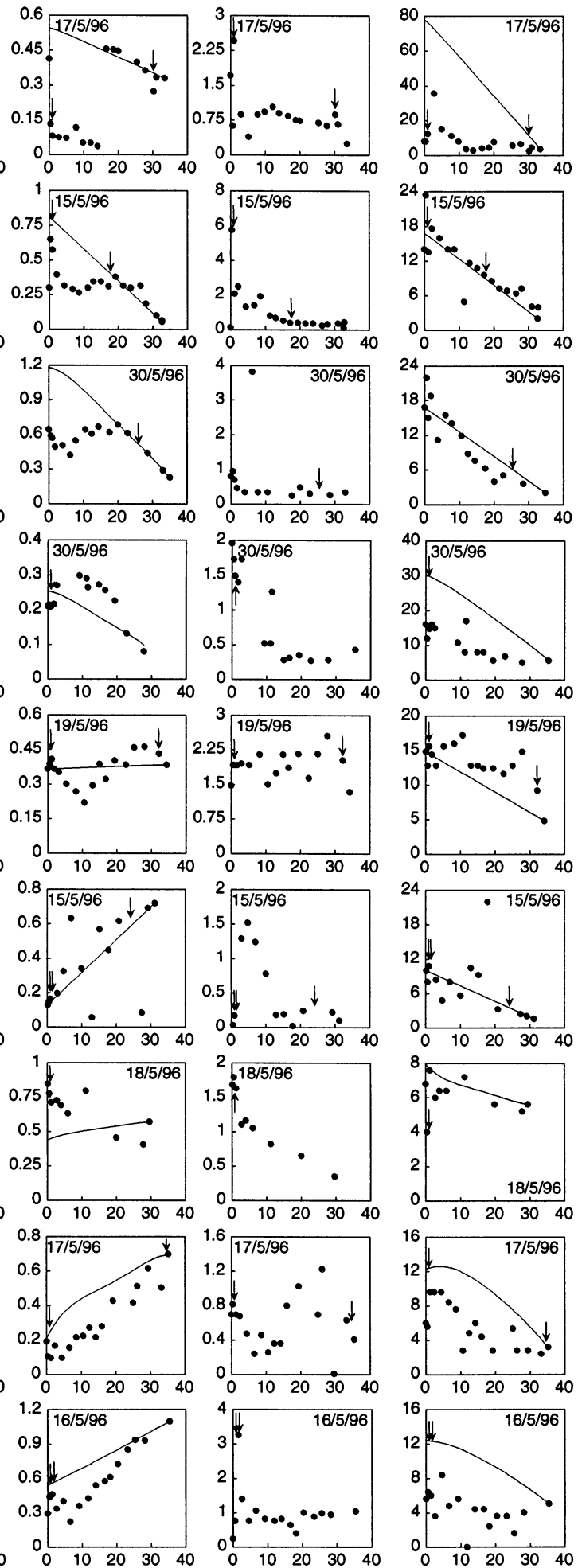

Salinity

Fig. 6. Run 3. Total nitrogen (TN), total phosphorus (TP), ammonium $\left(\mathrm{NH}_{4}{ }^{+}\right)$, nitrate $\left(\mathrm{NO}_{3}{ }^{-}\right)$, dissolved inorganic phosphorus (DIP), chlorophyll a (CHL-a), and total suspended sediments (TSS) in the 9 sub-tropical estuaries, plotted as a function of salinity for Run 1. Arrows show location of wastewater-treatment plants. Date $(\mathrm{d} / \mathrm{mo} / \mathrm{yr})$ is shown in each graph 


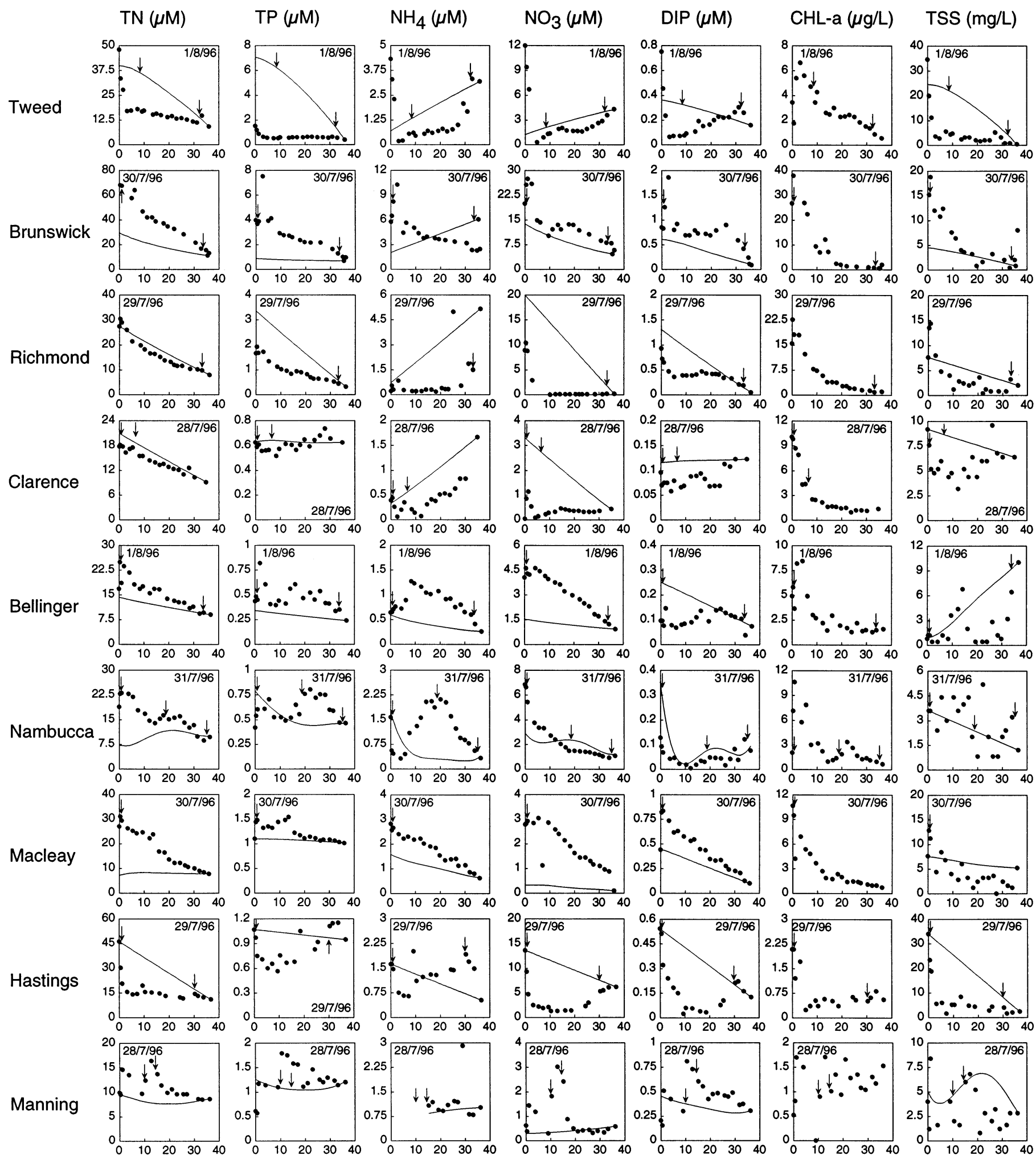

Salinity

Fig. 7. Run 4. Total nitrogen (TN), total phosphorus (TP), ammonium $\left(\mathrm{NH}_{4}{ }^{+}\right)$, nitrate $\left(\mathrm{NO}_{3}{ }^{-}\right)$, dissolved inorganic phosphorus (DIP), chlorophyll a (CHL-a), and total suspended sediments (TSS) in the 9 sub-tropical estuaries, plotted as a function of salinity for Run 1. Arrows show location of wastewater-treatment plants. Date $(\mathrm{d} / \mathrm{mo} / \mathrm{yr})$ is shown in each graph 


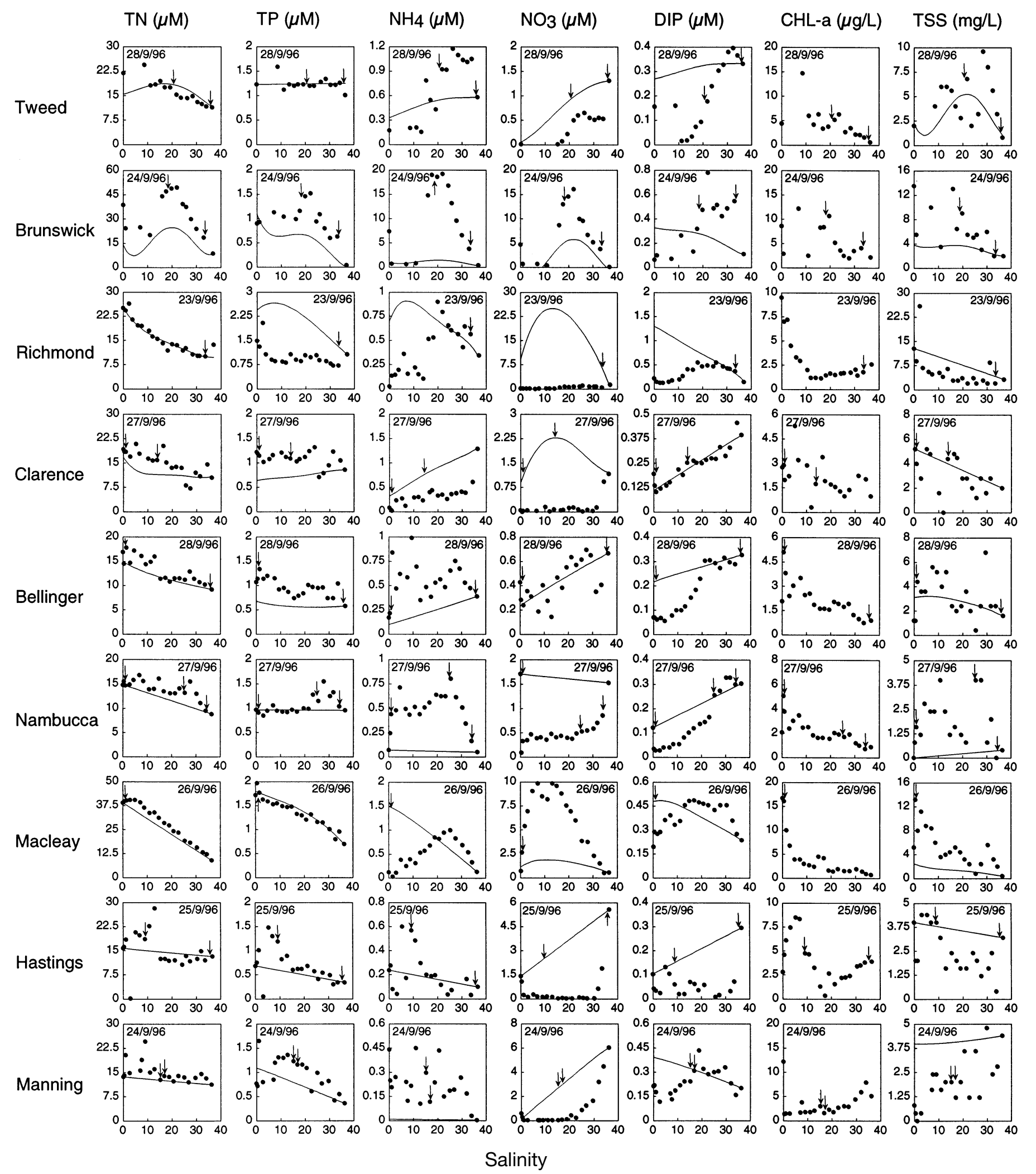

Fig. 8. Run 5. Total nitrogen (TN), total phosphorus (TP), ammonium $\left(\mathrm{NH}_{4}{ }^{+}\right)$, nitrate $\left(\mathrm{NO}_{3}{ }^{-}\right)$, dissolved inorganic phosphorus (DIP), chlorophyll a (CHL-a), and total suspended sediments (TSS) in the 9 sub-tropical estuaries, plotted as a function of salinity for Run 1. Arrows show location of wastewater-treatment plants. Date $(\mathrm{d} / \mathrm{mo} / \mathrm{yr})$ is shown in each graph 

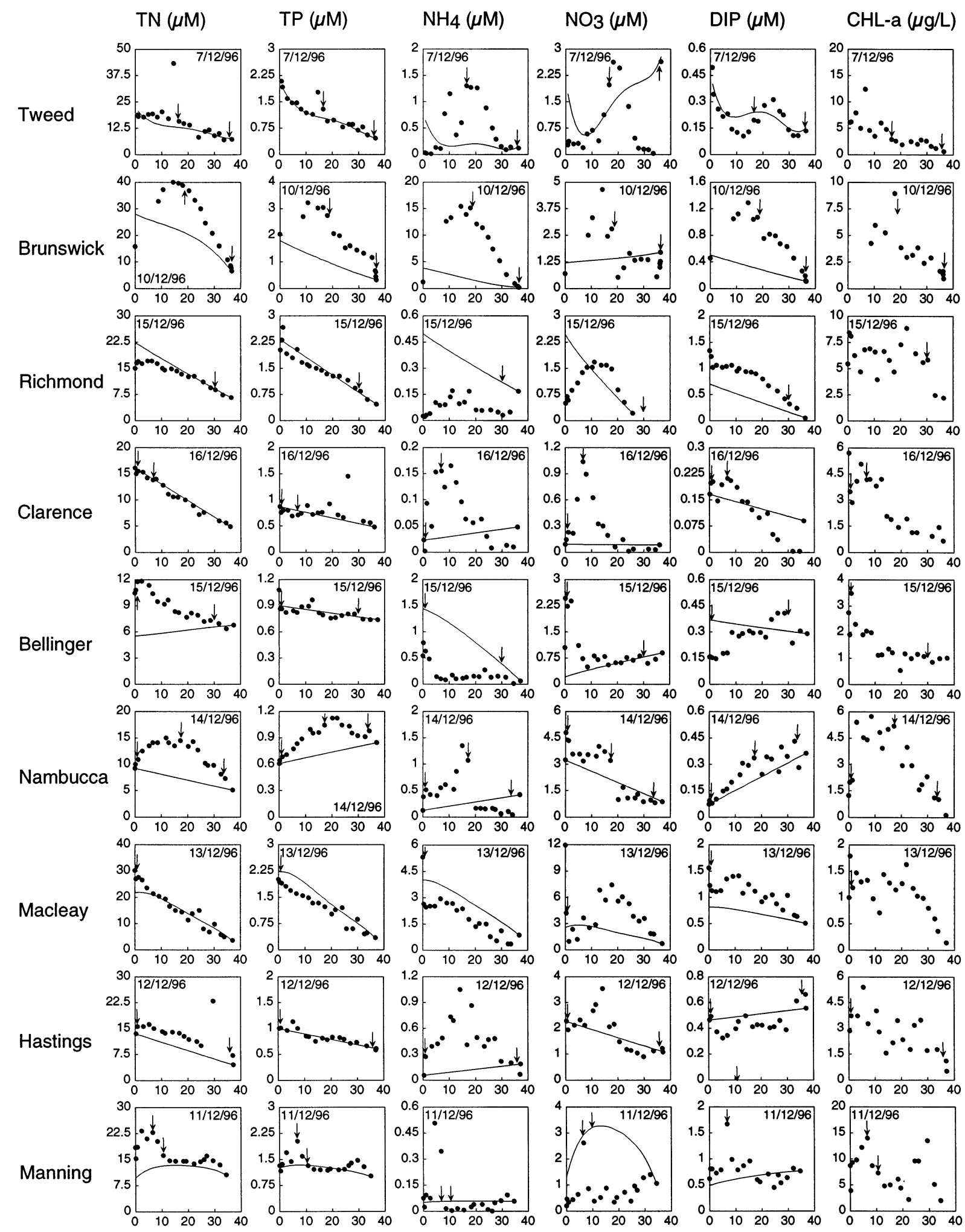

TSS (mg/L)
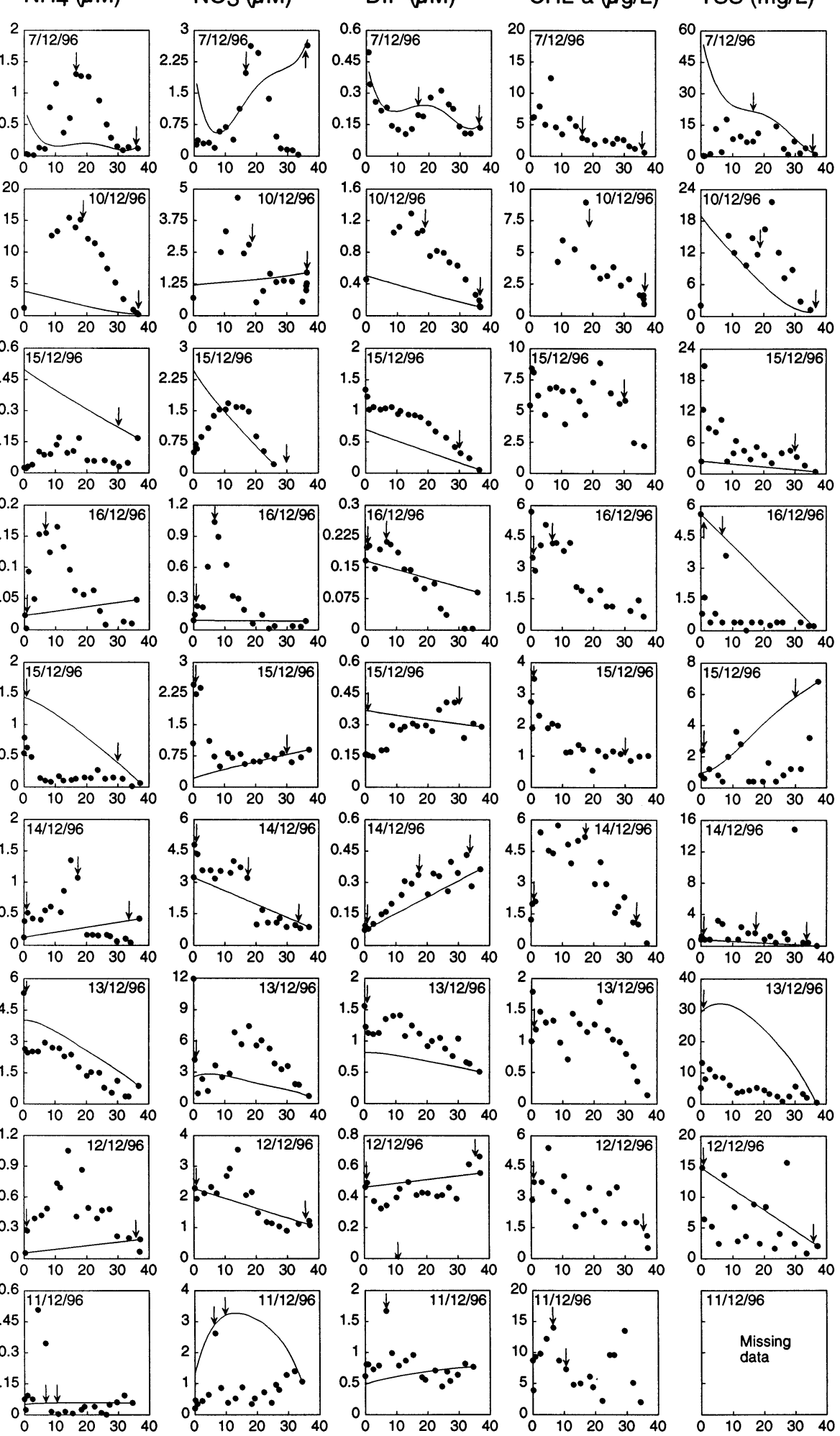

Salinity

Fig. 9. Run 6. Total nitrogen (TN), total phosphorus (TP), ammonium $\left(\mathrm{NH}_{4}^{+}\right)$, nitrate $\left(\mathrm{NO}_{3}^{-}\right)$, dissolved inorganic phosphorus (DIP), chlorophyll a (CHL-a), and total suspended sediments (TSS) in the 9 sub-tropical estuaries, plotted as a function of salinity for Run 1. Arrows show location of wastewater-treatment plants. Date $(\mathrm{d} / \mathrm{mo} / \mathrm{yr})$ is shown in each graph 


\section{Chlorophyll a}

Chlorophyll a (chl a) concentrations in all 9 estuaries for all runs ranged from 0.1 to $37.9 \mu \mathrm{g} \mathrm{l^{-1 }}$, with a median of $1.7 \mu \mathrm{g} \mathrm{l}^{-1}$, a mean of $3.0 \mu \mathrm{g} \mathrm{l}^{-1}$ and a standard deviation of $6.2 \mathrm{\mu g} \mathrm{l}^{-1}(\mathrm{n}=938)$ (Figs. 4 to 9). PN concentrations were positively correlated with chl a concentrations $(\mathrm{r}=+0.55 ; \mathrm{p}<0.001)$, indicating that a significant proportion of the PN was the result of autochthonous organic-matter production. The remaining variability in the chl a/TPN relationship most likely reflects PN delivered during floods. A chl a maximum occurred in the low-salinity region of nearly all 9 estuaries during nearly all runs. In most cases, the chl a maximum was restricted to a salinity of $<10$, but did spread out to a broader mid-estuary maximum in a number of systems during Run 6. Low-salinity chl a maxima have been noted in other river-dominated estuaries and ascribed to extended residence times in this region (e.g. Christian et al. 1991). Chl a concentrations varied considerably between estuaries and between runs. The highest and most variable chl $a$ concentrations occurred below a salinity of $\sim 5$ during Run 4, with maximum values ranging from $37.9 \mu \mathrm{g} \mathrm{l^{-1 }}$ in the Brunswick to $1.7 \mu \mathrm{g} \mathrm{l}^{-1}$ in the Manning. The lowest and least variable chl a concentrations occurred during Run 2, with maximum values between $\sim 3$ to $4 \mu \mathrm{g} \mathrm{l}^{-1}$ for most estuaries. Chl a concentrations in the outer sections of all 9 estuaries were generally low during all runs, rarely exceeding $2 \mu \mathrm{g} \mathrm{l}^{-1}$ at a salinity $>20$. Exceptions were evident in a number of estuaries during Run 5, where slightly higher chl a concentrations occurred at a salinity $>20$, although these values still remained below $5 \mu \mathrm{g}^{-1}$.

\section{Ammonium}

Ammonium $\left(\mathrm{NH}_{4}{ }^{+}\right)$concentrations in all 9 estuaries for all runs ranged from 0.01 to $19.23 \mu \mathrm{M}$, with a median of $0.85 \mu \mathrm{M}$, a mean of $1.79 \mu \mathrm{M}$ and a standard deviation of $2.62 \mu \mathrm{M}(\mathrm{n}=962)$ (Figs. 4 to 9). Mid-estuary $\mathrm{NH}_{4}{ }^{+}$maxima were seen in most estuaries during most runs due to wastewater inputs, except for the Richmond, which has no mid-estuary wastewater inputs. The exception was Run 3 following the May flood, when the locations of the mid-estuary $\mathrm{NH}_{4}^{+}$ maxima did not correspond with wastewater inputs, and a strong mid-estuary $\mathrm{NH}_{4}{ }^{+}$maxima was also exhibited in the Richmond. $\mathrm{NH}_{4}{ }^{+}$concentrations were negatively correlated with dissolved oxygen concentrations $(\mathrm{r}=-0.56 ; \mathrm{p}<0.001)$, suggesting wastewater organic loadings as the cause of lowered dissolved oxygen concentrations during Runs 2, 4, 5 and 6, and ammonification of flood-borne organic nitrogen during
Run 3. Some increase in $\mathrm{NH}_{4}{ }^{+}$concentrations in the freshwater end-members occurred in most estuaries following flood events (i.e. Runs 1 and 3). For example, $\mathrm{NH}_{4}{ }^{+}$concentrations of $1.80,4.00,7.14$ and $5.03 \mu \mathrm{M}$ were measured at the mouths of the Tweed, Brunswick, Richmond and Clarence estuaries, respectively, during the flood peak on 5 May 1996. However, these increased concentrations were much less than the midestuary maximum concentrations during the dry season. The highest $\mathrm{NH}_{4}{ }^{+}$concentrations occurred in the Brunswick Estuary during the dry season Runs 2, 5 and 6 , with maximum values in each of the 3 runs of $>15 \mu \mathrm{M}$.

Removal of $\mathrm{NH}_{4}{ }^{+}$, as indicated by concentrations falling below the actual mixing line, occurred in a number of estuaries during a number of runs and always corresponded with a peak in chl a concentrations, suggesting phytoplankton uptake. In some cases it appears that $\mathrm{NH}_{4}{ }^{+}$removal occurred, although concentrations did not fall below the actual mixing line because uptake was superimposed on large wastewater inputs. Examples of this superimposed removal of $\mathrm{NH}_{4}{ }^{+}$as a result of phytoplankton uptake occurred around a salinity of 10 during Run 1, and below a salinity of 10 during Run 5 in the Brunswick. The lowest $\mathrm{NH}_{4}{ }^{+}$concentrations occurred in most estuaries during Run 5, when concentrations dropped below $1.2 \mu \mathrm{M}$ in all estuaries except the Brunswick, and $\mathrm{NH}_{4}{ }^{+}$minima of $<0.3 \mu \mathrm{M}$ occurred in the Tweed, Richmond, Clarence, Macleay and Manning. $\mathrm{NH}_{4}{ }^{+}$minima of $<0.3 \mu \mathrm{M}$ also occurred during Run 6 in the Tweed, Richmond, Bellinger and Manning, and during Run 4 in the Richmond. The minimum $\mathrm{NH}_{4}{ }^{+}$concentrations during Runs 4, 5 and 6 corresponded with maximum chl a concentrations.

\section{Nitrate}

Nitrate $\left(\mathrm{NO}_{3}{ }^{-}\right)$concentrations in all 9 estuaries for all runs ranged from 0.01 to $72.04 \mu \mathrm{M}$ with a median of $1.66 \mu \mathrm{M}$, a mean of $4.04 \mu \mathrm{M}$ and a standard deviation of $6.73 \mu \mathrm{M}$ ( $\mathrm{n}=960)$ (Figs. 4 to 9). In most cases these $\mathrm{NO}_{3}{ }^{-}$maxima coincided with $\mathrm{NH}_{4}{ }^{+}$maxima, which also suggested wastewater inputs as the source of $\mathrm{NO}_{3}{ }^{-}$. The freshwater end-members generally had the highest $\mathrm{NO}_{3}{ }^{-}$concentrations following flood events (i.e. Runs 1 and 3), but these concentrations quickly decreased. For example, by Run 3, which was about 2 to 3 wk after the May flood, $\mathrm{NO}_{3}{ }^{-}$concentrations had already decreased significantly from the 9.60, 15.86, $10.80,5.03 \mu \mathrm{M}$ concentrations measured at the mouths of the Tweed, Brunswick, Richmond and Clarence estuaries respectively during the flood peak from 5 to 7 May 1996. Mid-estuary $\mathrm{NO}_{3}{ }^{-}$maxima were seen in 
Tweed and Richmond during Run 1, the Tweed and Brunswick during Run 2, the Tweed, Brunswick, Bellinger and Manning during Run 3, the Bellinger and Macleay during Run 4, the Brunswick and Macleay during Run 5, and Brunswick, Clarence, Macleay and Hastings during Run 6. In the Tweed, this dry-season maximum exceeded the highest $\mathrm{NO}_{3}{ }^{-}$concentrations measured during flood events.

Removal of $\mathrm{NO}_{3}^{-}$, as indicated by concentrations falling below the actual mixing line, occurred in a number of estuaries during a number of runs, and in most cases corresponded with a peak in chl a concentrations, suggesting phytoplankton uptake. Almost complete $\mathrm{NO}_{3}{ }^{-}$removal occurred in the Richmond and Clarence during Run 4, and the Richmond, Clarence, Hastings and Manning during Run 5, with most concentrations falling below $0.1 \mu \mathrm{M}$. Almost complete depletion of water-column nutrient stocks is also commonly seen in temperate estuaries during phytoplankton blooms (Rudek et al. 1991, Cloern 1996). In some cases it appears that $\mathrm{NO}_{3}{ }^{-}$removal may have occurred, although concentrations did not fall below the actual mixing line because uptake was superimposed on large wastewater inputs. Examples of this superimposed removal of $\mathrm{NO}_{3}{ }^{-}$resulting from phytoplankton uptake occurred around a salinity of 8 during Run 1 in the Tweed, around a salinity of 8 during Run 4 in the Brunswick, and below a salinity of 10 during Run 5 in the Brunswick. The lowest $\mathrm{NO}_{3}{ }^{-}$concentrations occurred in most estuaries during Run 5, when there was almost complete removal in the Richmond, Clarence, Hastings and Manning along much of the salinity gradient. Almost complete $\mathrm{NO}_{3}{ }^{-}$removal also occurred in the Richmond, Clarence and Hastings during Run 4.

\section{Total nitrogen}

Total nitrogen (TN) concentrations in all 9 estuaries for all runs ranged from 0.07 to $170.94 \mu \mathrm{M}$, with a median of $16.93 \mu \mathrm{M}$, a mean of $22.23 \mu \mathrm{M}$ and a standard deviation of 16.21 $\mathrm{MM}(\mathrm{n}=975)$ (Figs. 4 to 9), and were positively correlated with $\mathrm{NO}_{3}^{-}$concentrations ( $\mathrm{r}=$ $+0.69 ; \mathrm{p}<0.001)$, DON ( $\mathrm{r}=+0.71 ; \mathrm{p}<0.001)$, PN ( $\mathrm{r}=$ $+0.72 ; \mathrm{p}<0.001)$, TP concentrations $(\mathrm{r}=+0.62 ; \mathrm{p}<$ $0.001)$, TSS concentrations $(\mathrm{r}=+0.51 ; \mathrm{p}<0.001)$, and negatively correlated with dissolved oxygen concentrations $(\mathrm{r}=-0.52 ; \mathrm{p}<0.001)$ and $\mathrm{pH}(\mathrm{r}=-0.59 ; \mathrm{p}<0.001)$. The highest TN concentrations generally occurred following the January and May flood events (i.e. Runs 1 and 3), and the majority of this nitrogen consisted of DON and PON. Following flood events (i.e. Runs 1 and 3), TN concentrations generally showed linear distributions. By Run 3, however, which was about 2 to 3 wk af- ter the May flood, TN concentrations had already decreased from the 40.03, 40.93, 78.02 and $53.92 \mu \mathrm{M}$ concentrations measured at the mouths of the Tweed, Brunswick, Richmond and Clarence estuaries, respectively, during the flood peak from 5 to 7 May 1996. The dry-season runs showed a range of behaviours for $\mathrm{TN}$ concentrations. TN concentrations in the Richmond and Clarence consistently showed linear distributions. The estuaries that showed inputs of TN, as indicated by an upward curvature (e.g. Brunswick), also had large inputs of $\mathrm{NH}_{4}{ }^{+}$and $\mathrm{NO}_{3}{ }^{-}$, suggesting wastewater loading as the source. PN concentrations (data not shown) decreased during the dry-season runs, and TN concentrations dominantly consisted of $\mathrm{NH}_{4}{ }^{+}, \mathrm{NO}_{3}{ }^{-}$and DON forms.

\section{Total phosphorus}

Total phosphorus (TP) concentrations in all 9 estuaries for all runs ranged from 0.03 to $7.51 \mu \mathrm{M}$, with a median of $1.12 \mu \mathrm{M}$, a mean of $1.24 \mu \mathrm{M}$ and a standard deviation of $0.69 \mu \mathrm{M}(\mathrm{n}=977)$ (Figs. 4 to 9$)$, and were positively correlated with DIP concentrations $(\mathrm{r}=+0.61$; $\mathrm{p}<0.001)$, DOP concentrations $(\mathrm{r}=+0.50 ; \mathrm{p}<0.001)$, PP concentrations $(r=+0.84$; $p<0.001)$, and TN concentrations $(\mathrm{r}=+0.62 ; \mathrm{p}<0.001)$. Following flood events, TP concentrations increased slightly, but much less so than nitrogen. For example, TP concentrations of $1.93,1.20,5.26$ and $1.88 \mu \mathrm{M}$ measured at the mouths of the Tweed, Brunswick, Richmond and Clarence estuaries, respectively, during the flood peak of 5 to 7 May 1996 were only slightly different from the freshwater end-member TP concentrations during Run 3. There were no clearly distinct differences in TP concentrations between estuaries for all 6 runs, except for the Brunswick and Richmond, which commonly had slightly higher concentrations. Following the small January flood event (i.e. Run 1), TP concentrations in most estuaries showed a concave downward distribution, indicating that most of the estuaries trap a proportion of their post-flood catchment TP load. A similar trapping of TP was not seen following the May flood (i.e. Run 3), when most estuaries displayed either a linear or concave upward distribution of TP. Runs 2, 3 and 4 showed a variety of TP distributions in all 9 estuaries, and Run 6 showed mainly linear distributions, except for the Brunswick, Bellinger and Nambucca, which showed concave upward distributions.

\section{Dissolved inorganic phosphorus}

Dissolved inorganic phosphorus (DIP) concentrations in all 9 estuaries for all runs ranged from 0.01 to 
$2.22 \mu \mathrm{M}$, with a median of $0.32 \mu \mathrm{M}$, a mean of $0.39 \mu \mathrm{M}$ and a standard deviation of $0.31 \mu \mathrm{M}(\mathrm{n}=968)$ (Figs. 4 to 9). TP concentrations were positively correlated with DIP concentrations $(\mathrm{r}=+0.61$; $\mathrm{p}<0.001)$. Mid-estuary DIP maxima were seen in the Brunswick during all the dry-season runs (i.e. 2, 4, 5 and 6), and in most cases these DIP maxima coincided with $\mathrm{NO}_{3}{ }^{-}$and $\mathrm{NH}_{4}{ }^{+}$maxima, which also suggests wastewater inputs as the source of DIP. The freshwater end-member generally had the highest DIP concentrations following flood events (i.e. Runs 1 and 3), but similar to TP these increases were much smaller than post-flood increases in $\mathrm{NH}_{4}{ }^{+}$and $\mathrm{NO}_{3}{ }^{-}$. For example DIP concentrations of $0.74,0.83,0.63$ and $0.30 \mu \mathrm{M}$ measured at the mouths of the Tweed, Brunswick, Richmond and Clarence estuaries respectively during the flood peak of 5 to 7 May 1996 were only slightly different from the freshwater end-member DIP concentrations during Run 3.

Removal of DIP, as indicated by concentrations falling below the actual mixing line, occurred in the low-salinity regions of many of the estuaries during all the runs and was typically associated with an input of DIP, as indicated by concentrations falling above the actual mixing line at high salinities. DIP removal always corresponded with a peak in chl a concentrations, suggesting phytoplankton uptake. Similar to $\mathrm{NH}_{4}{ }^{+}$, DIP removal occurred around a salinity of 10 during Run 4 in the Brunswick, although concentrations did not fall below the actual mixing line because uptake was superimposed on large wastewater inputs. During Run 5, all the estuaries showed an increase in DIP concentrations at higher salinities, and the seawater end-members were consistently around $0.3 \mu \mathrm{M}$.

\section{DISCUSSION}

\section{Use of modified mixing diagrams}

Modified mixing diagrams were used in this study to avoid 'apparent' non-linear distributions arising from river-source variations on a time scale less than or equal to the flushing time of the estuary. This has been shown previously (e.g. Loder \& Reichard 1981, Officer \& Lynch 1981, Cifuentes et al. 1990) and in this study to be an important consideration when interpreting mixing plots. For example, use of a theoretical mixing line for TN in the Manning Estuary during Run 2 would have suggested a $27 \%$ change in TN in the estuary. In contrast, the use of a conservative mixing line showed only a $7 \%$ change.

Of more importance, however, was when a large discrepancy occurred between the measured freshwater end-member and the freshwater end-member indicated by the conservative mixing line. This results from either a source or sink in the tidal river or at the head of the estuary, and would dramatically alter the interpretation of the mixing plot if a theoretical mixing line were used. For example, use of a theoretical mixing line for $\mathrm{NO}_{3}{ }^{-}$in the Bellinger Estuary during Run 4 would have suggested almost conservative behaviour in the estuary, which is the case, but would have missed the large source, because the wastewater inputs are at the head of the estuary. Similarly, use of a theoretical mixing line for DIP in the Richmond Estuary during Run 3 would have underestimated the amount of removal at the head of the estuary, and would have suggested an apparent downstream source. As such, if variations in river concentrations at the head of the estuary and flushing times are included in estuarine monitoring programs, conservative mixing lines can be calculated. This will improve the interpretation of mixing diagrams, making them a valid, robust and convenient method suitable for the routine evaluation of nutrient transformations at the land-sea interface.

\section{General patterns of biogeochemical behaviour}

Although patterns of biogeochemical processes may be developed easily for individual systems, estuaries are complex, and differences between systems usually hinder the extrapolation of the findings for one estuary to another (Pennock et al. 1994). Comparative studies, such as this one, allow identification of general patterns of behaviour, and distinct differences, that occur across a number of systems of the same class (e.g. river-dominated sub-tropical). As such, conceptual understandings that develop from comparative studies should present a more robust paradigm than concepts based on an individual system.

\section{Impact of floods}

Elevated total and dissolved nitrogen and phosphorus and suspended-sediment concentrations immediately following flood events reflect erosion and leaching of material from the catchments (Fig. 10). At least $40 \%$ of most of the 9 catchments have been cleared, mostly for agriculture and grazing (Table 1). Nitrogen concentrations showed a much larger increase than phosphorus concentrations, and most (66 to $95 \%$ ) of the TN was delivered as dissolved and particulate organic forms. This contrasts with some disturbed, temperate, overseas systems, to which much of the TN is commonly delivered as DIN (e.g. Christian et al. 1991), but is similar to many other rivers around the world (Seitzinger \& Sanders 1997). However, these elevated concentrations decrease 
rapidly following flood events because of rapid flushing of the estuary.

During the May flood, the 4 northern, and most likely the 5 southern, estuaries flushed fresh to the mouth, allowing most of the flood-borne material to escape from the estuary (Fig. 10; Eyre \& Twigg 1997, Eyre et al. 1998). McKee et al. (2000) have demonstrated that flushing during floods results in the Richmond River Estuary having a low nutrientretention efficiency (TN $<2.5 \%$; $\mathrm{TP}<$ $5.4 \%$ ), suggesting that all river-dominated sub-tropical Australian estuaries that flush fresh to the mouth are also likely to have a low nutrientretention efficiency (Eyre 1998). As such, very little of the annual diffuse nutrient load is available for maintaining phytoplankton growth in the estuary, giving more importance to the annual wastewater load which discharges constantly throughout the year (see 'Factors controlling phytoplankton growth' below).

Immediately following the January and May floods, TSS concentrations in many of the estuaries fell below the conservative mixing line, indicating that a proportion of the post-flood catchment suspended-sediment load was trapped. There are 2 mechanisms behind this post-flood trapping depending on the size of the flood. During small floods (January), the estuaries do not flush fresh to the mouth and sediment deposition is associated with tidal back-push which increases the travel time of the flood water (i.e. decreased velocity) through the estuary allowing sediment to settle (Hossain 1997). In contrast, following larger floods (May), these estuaries recover by way of a salt wedge intruding along the channel bottom and forming a distinct halocline, and the salt water-freshwater interface moves slowly landward. Some of the sediment from the sediment-laden upper layer (represented by the mixing plot) most likely settles through the halocline at slack water, when it is caught in the lower layer, transported landward, and deposited near the salt water-freshwater interface (Fig. 10; Eyre \& Twigg 1997, Hossain 1997).

\section{Factors controlling phytoplankton growth}

Light and nutrient-resource limitation are typically the 2 major factors controlling phytoplankton growth (Valiela 1995). Although TSS concentrations were elevated immediately following the January and May
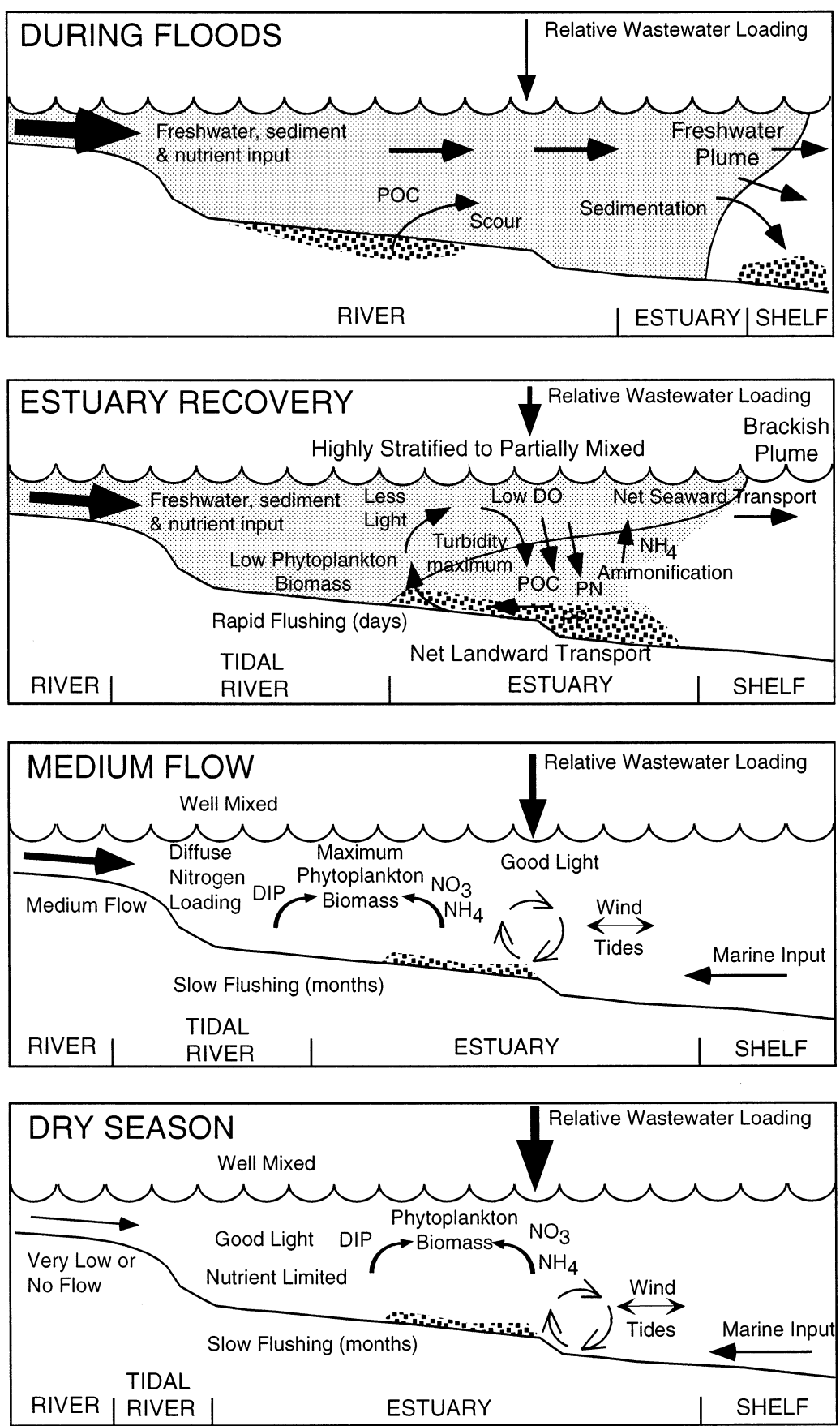

Fig. 10. Four-stage conceptual model of typical yearly cycle of nutrient delivery and transformation and phytoplankton growth in sub-tropical east Australian estuaries. Expanded from Eyre's (1998) general model for wet and dry tropical and sub-tropical Australian estuaries 
floods (i.e. Runs 1 and 3), the mixing depth/photic depth only exceeded 5 in the Richmond and Clarence estuaries, suggesting that light was not limiting across all the estuaries (Cole \& Cloern 1984, Grobler 1985). Despite adequate light and increased nutrient-loading to the estuary during floods, phytoplankton biomass did not accumulate (i.e. low chl a concentrations), suggesting that rapid flushing may limit biomass accumulation (Cloern 1996, Table 3). During Runs 2, 4, 5 and 6 there was sufficient light (i.e. mixing depth/photic depth $<5$ and commonly $<1$ ) for phytoplankton growth in all the estuaries, and residence times were long (Table 3). However, with the exception of the Brunswick, chl a concentrations during Runs 2, 4, 5 and 6 were nearly always restricted to $<5 \mu \mathrm{g} \mathrm{l^{-1 }}$ above a salinity of 10 , and only exceeded $12 \mu \mathrm{g} \mathrm{l}^{-1}$ below a salinity of 10 for 12 samples, suggesting nutrient limitation.

Nutrient limitation comprises the restriction of phytoplankton growth rates and biomass accumulation through the low availability of a nutrient (Fisher et al. 1995). A number of methods have been used to identify potentially limiting nutrients in estuarine systems; 3 are available for this study: comparison of extracellular nutrient ratios to the Redfield ratio (Fisher et al. 1992), comparison of ambient nutrient concentrations to halfsaturation constants for phytoplankton uptake (Fisher et al. 1988), and response to external nutrient-loading (Borum 1996, see also 'Impact of different nutrient sources' below). Phytoplankton require external dissolved inorganic nutrients in the molar ratio of $16: 1$. If this ratio falls below 10:1, biomass development may be nitrogen-limited, and if a ratio of >20:1 occurs, phosphorus limitation may result (Boynton et al. 1982), although exceptions to these general rules often occur (Fisher et al. 1995). The half-saturation constant is a concentration at which nutrient uptake is half its maximum value, and concentrations below these values can limit algal growth rates (Fisher et al. 1992). Typical half-saturation values are 1.0 to $2.0 \mu \mathrm{M}$ for DIN, 0.1 to $0.5 \mu \mathrm{M}$ for DIP and 1.0 to $5.0 \mu \mathrm{M}$ for silicate; it is not known, however, how valid these values are for lownutrient sub-tropical waters. Although no single method is unequivocal in demonstrating nutrient limitation, the use of 3 independent measures, all illustrating a similar trend, provides strong evidence for potential nutrient-limitation.

During Runs 4, 5 and 6 (dry season) when maximum chl a concentrations occur, 52 and $81 \%$ of the samples in all estuaries, except Brunswick, had DIN and DIP concentrations, respectively, that fell below the upper half-saturation constants for phytoplankton uptake, suggesting the potential for nutrient limitation of growth rate. In contrast, only 4 and $47 \%$ of the samples in the Brunswick had DIN and DIP concentrations, respectively, below the upper half-saturation constant, indicating that nutrients were unlikely to be limiting to growth rates. There were distinct differences between estuaries with regard to which nutrient was most likely to be potentially limiting to biomass development during the dry season. Most (84\%) dry season samples in the Richmond, Clarence and Manning had DIN:DIP ratios $<10$, suggesting the potential for $\mathrm{N}$ limitation of biomass, while the Brunswick was most likely potentially P-limited, with most $(74 \%)$ dry season samples having DIN:DIP ratios $>20$. No individual nutrient appeared to be potentially limiting to biomass development in the Tweed, Bellinger, Nambucca, Macleay and Hastings, with $40 \%$ of the samples having DIN:DIP ratios $<10,23 \%$ of the samples having DIN: DIP ratios between 10 and 20 , and $37 \%$ of the samples having DIN:DIP ratios $>20$. Only about $5 \%$ of the samples during Runs 2, 4, 5 and 6 had silicate concentrations below the upper half-saturation constant for phytoplankton uptake, indicating that silicate is unlikely to be limiting to growth rate. Consistent with this is the negative correlation $(\mathrm{r}=-0.64 ; \mathrm{p}=0.001)$ between silicate and salinity, illustrating that silicate generally behaves conservatively in the 9 estuaries. Because these sub-tropical estuaries are potentially nutrient-limited and have a light and flushing regime that only constrains algal growth and biomass accumulation for short periods during and immediately following floods (Fig. 10), they will be very susceptible to the effects of further nutrient enrichment. The effects of further nutrient enrichment will be amplified during the dry season, from July to December, when growth rates are high and residence times are long.

It appears that the type of loadings each system received controls the type of potential limitation, either $\mathrm{N}$ or P. The 3 potentially N-limited systems (Richmond, Clarence and Manning) received small wastewater loadings, the potentially P-limited system (Brunswick) received the largest wastewater loading, and the systems with potentially balanced $\mathrm{N}$ and $\mathrm{P}$ limitation (Tweed, Bellinger, Nambucca, Macleay, Hastings) received moderate wastewater loadings. This is highlighted by the good logarithmic relationship $\left(\mathrm{r}^{2}=0.82\right.$; $\mathrm{p}<0.01$ ) between wastewater DIN loadings and median DIN:DIP ratios in the 9 sub-tropical estuaries (Fig. 11). However, the water-column DIN:DIP ratios are not directly linked to the wastewater loading because the effluent delivered to the 9 estuaries has an average DIN:DIP ratio of about 2.3. Therefore, there must be a recycling mechanism that increases the water-column DIN concentrations and/or decreases DIP concentrations in the water column in response to increased wastewater loadings.

One possible cause of increasing median water-column DIN:DIP ratios with increasing wastewater load- 


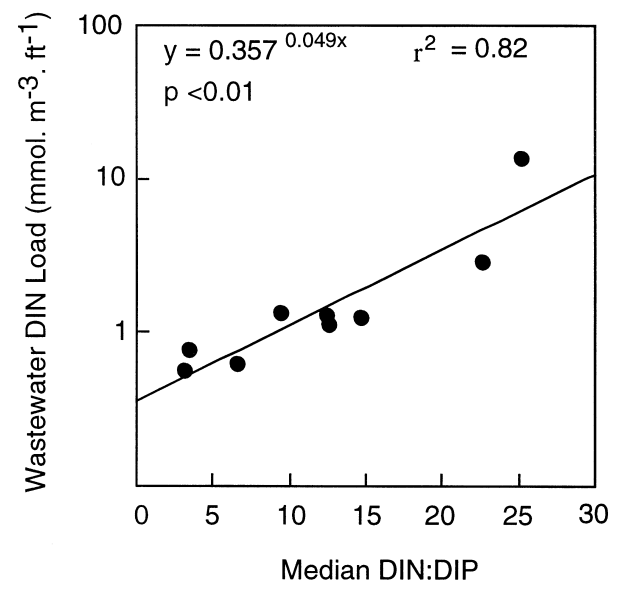

Fig. 11. Wastewater DIN loading index plotted as a function of median DIN:DIP ratio in the 9 sub-tropical estuaries. $\mathrm{ft}=$ flushing time

ings (Fig. 11) is the stimulation of both water-column phytoplankton and benthic microalgae. The subsequent breakdown of the excess organic matter produced by the sedimentation of the phytoplankton biomass from the water column releases nitrogen and phosphorus. However, the growth of benthic microalgae injects oxygen into the sediment, trapping released DIP in the oxidised upper-sediment layers (Graneli \& Sundback 1985, Carlton \& Wetzel 1988). In contrast, DIN passes freely into the water column, increasing the DIN:DIP ratio. Consistent with this is the stimulation of phytoplankton and benthic microalgae, and the trapping of phosphorus, in the bottom sediment in the Brunswick Estuary (A. Ferguson pers. comm.).

\section{Impact of different nutrient sources}

Because phytoplankton growth in the 9 sub-tropical estuaries in this study is potentially nutrient-limited, the delivery of nutrients, and the timing and quantity of this delivery, are critical to understanding the response of phytoplankton throughout the year. The impact of nutrient delivery is dependent not only on the load, but also on the source and timing of the load and the volume and residence time of the estuary into which it is discharged. To incorporate all 5 of these important factors (load, source, timing, volume, residence time) into 1 term, a nutrient loading index was developed. This index consists of the daily wastewater or diffuse load (mmol) multiplied by the flushing time (ft) of the estuary in days during each of the runs divided by the estuary volume $\left(\mathrm{m}^{3}\right)$.

Both maximum and mean chl a concentrations in all 9 estuaries for Runs 1, 3, 4 and 6 are well correlated with the wastewater DIN loading index (Fig. 12a,b).
However, the Richmond, Clarence and Manning estuaries have high maximum and mean chl a concentrations for low wastewater DIN loading indices, as shown by the trend of data points along the bottom of Fig. 12a,b. Removal of the Richmond, Clarence and Manning estuaries, which all have a wastewater DIN loading index $<1$, results in a significant improvement in the relationship between maximum and mean chl a concentrations and the wastewater DIN loading index (Fig. 12c,d).

The Richmond, Clarence and Manning estuaries show a poor relationship between maximum and mean chl a concentrations, and the wastewater DIN loading index for Runs 1, 3, 4 and $6\left(\mathrm{r}^{2}<0.100\right)$. In contrast, there are some weak, but not significant, relationships between maximum and mean chl a concentrations and the diffuse DIN loading index for some runs $\left(\mathrm{r}^{2}=0.56\right.$ to $0.84 ; \mathrm{p}=0.21$ to 0.62 ). This suggests that in those systems that receive a low wastewater DIN load, the diffuse DIN loading index becomes a more important control on chl a concentrations. This is particularly obvious during Run 4, where the highest chl a concentrations recorded for the Richmond and Clarence occurred at the head of the estuary (Fig. 7). There was a small runoff event in July (Fig. 2), which is reflected in the freshwater end-member $\mathrm{NO}_{3}{ }^{-}$concentrations, which were elevated above concentrations that occurred during the other dry season runs (i.e. 2, 5 and $6)$. This July runoff was sufficient to increase diffuse loading to the estuaries, but not large enough to rapidly flush the systems (Fig. 10, Table 3). This July event also appears to have stimulated phytoplankton growth at the head of the Bellinger, Nambucca and Macleay estuaries (Fig. 7), but overall phytoplankton growth is more significantly correlated to the wastewater DIN loading index than the diffuse DIN loading index in these systems.

The control of chl a concentrations by nutrient loadings (Fig. 12) provides further evidence for nutrients being potentially the major factor limiting phytoplankton growth in the 9 sub-tropical estuaries. However, it is clearly not just the nutrient loadings that are important but also the estuary hydrography (volume and intra-annual variability in flushing times). For example, chl a concentrations were low in all the estuaries during Run 3 due to rapid flushing (Table 3), despite receiving the same daily wastewater, and increased, diffuse, phosphorus and nitrogen loadings. Similarly, the Clarence Estuary receives the third largest nitrogen and phosphorus wastewater loadings (Fig. 13), but its large volume reduces the loadings to a low loading index and corresponding low chl a concentrations. In contrast, the Brunswick Estuary receives the lowest nitrogen and phosphorus wastewater loadings (Fig. 13), but its small volume and medium flushing 

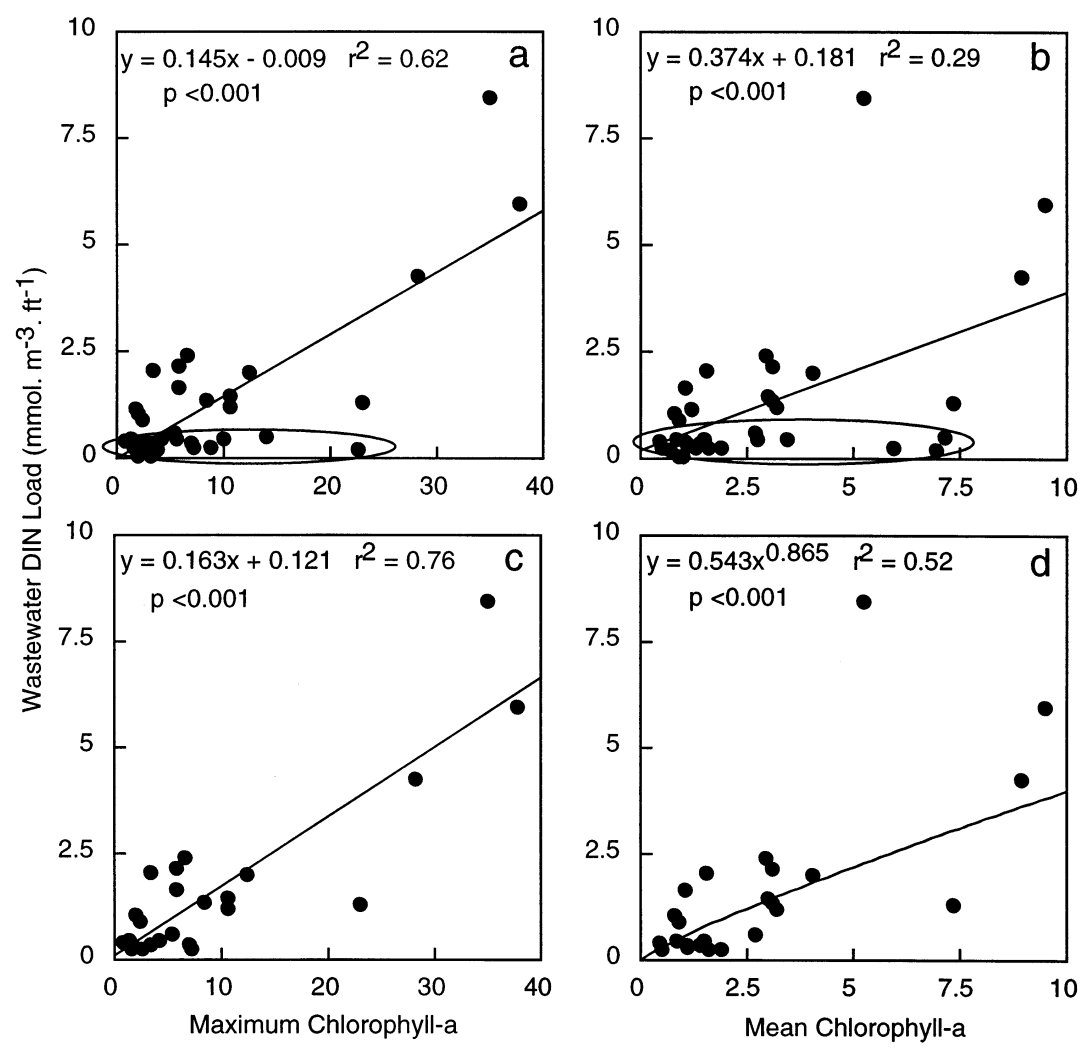

Fig. 12. Wastewater DIN loading index plotted as a function of (a) and (b) maximum and mean chlorophyll a concentrations in the 9 sub-tropical estuaries, respectively; and (c) and (d) maximum and mean chlorophyll a concentrations in 6 sub-tropical estuaries (i.e. excluding Richmond, Clarence and Manning), respectively

times result in a very high loading index and corresponding elevated chl a concentrations. This highlights the importance of physical processes in modifying biological responses.

\section{Contrasts with temperate systems}

Maximum phytoplankton biomass ( $\mathrm{chl}$ a) in the 9 sub-tropical estuaries occurred in July (winter) in response to an episodic runoff event, which delivered nutrients to the upper estuary (Fig. 10). Maximum growth (as inferred from nutrient depletion) occurred in September (spring), most likely in response to increasing temperature and light and long flushing time (Fig. 10). This contrasts with many temperate estuaries, in which maximum biomass typically occurs in spring and maximum productivity typically occurs in summer (Malone 1992). These differences may reflect differences in temperature, which would be less limiting during winter in the 9 sub-tropical estuaries (i.e. mean July water temperature $=15.9^{\circ} \mathrm{C}$ ). However, winter phytoplankton blooms do occur in temperate systems (Sellner et al. 1991), sometimes in response to runoff events (Rudek et al. 1991), and maximum phytoplankton productivity in sub-tropical estuaries can occur during summer in response to runoff events (O'Donohue \& Dennison 1997). As such, the major differences between climatic regions, which determine the temporal patterns of phytoplankton growth, appear to be the timing and magnitude of hydrologic factors. Nutrient delivery to sub-tropical Australian estuaries is episodic, with a high inter- and intra-variability (Eyre 1998), and lacks a persistent, although still variable, annual event such as a spring-flood nutrient load commonly seen in temperate systems (Harding 1994). As such, sub-tropical Australian estuaries are characterised by a high degree of variability in nutrient delivery and phytoplankton growth. Similar variability has been described for warm-temperate and sub-tropical estuaries in the Gulf of Mexico (Pennock et al. 1999).

Many partially mixed temperate estuaries trap a proportion of the spring-flood nutrient load, which is then recycled to fuel the summer productivity maximum (Kemp \& Boynton 1984, Malone 1992). As such, nutrient loading and phytoplankton growth are out of phase. This contrasts with the 9 well-mixed sub-tropical estuaries in this study, where nutrient loading and phytoplankton growth (chl a) appear to be in phase (Fig. 12). As such, recycled nutrients may play a smaller role in 

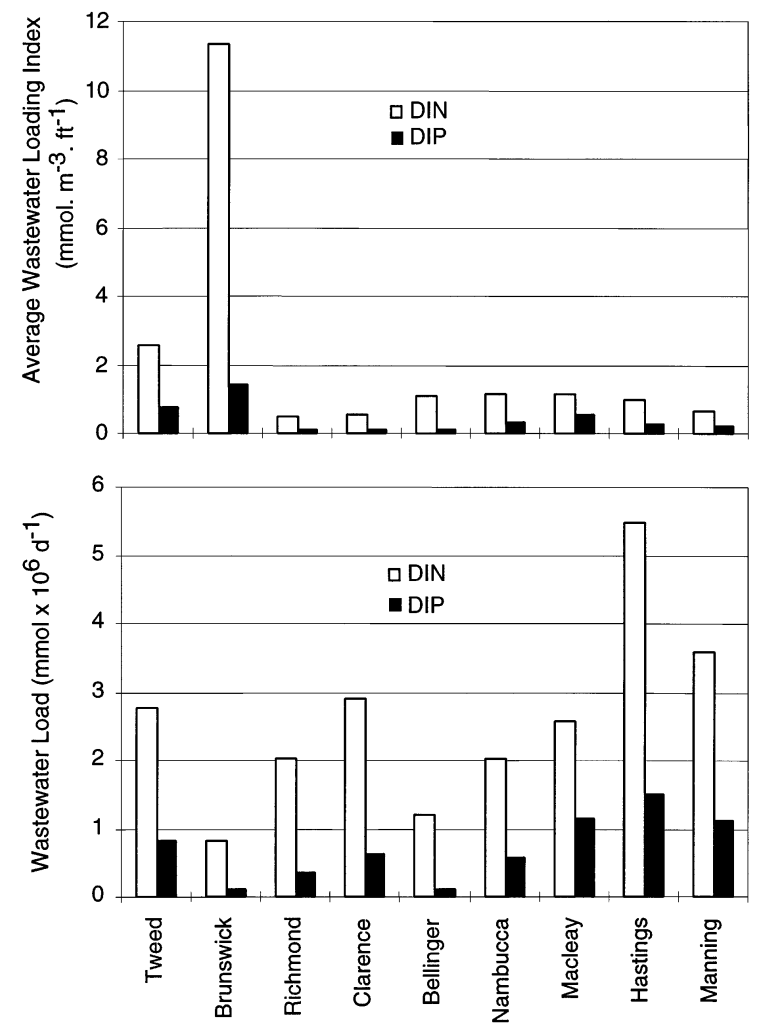

Fig. 13. Comparison of wastewater DIN and DIP loading indexes and wastewater DIN and DIP load for the 9 subtropical estuaries

maintaining phytoplankton growth in these types of systems compared to the larger, partially mixed, temperate estuaries. Consistent with this is the low nutrient-retention efficiency of sub-tropical estuaries (Eyre 1997a, 1998, McKee et al. 2000) which results in little material being available for storage, recycling and outof-phase phytoplankton growth. However, phytoplankton growth was also in phase with nutrient loading in the well-mixed, river-dominated, temperate, lower Neuse River Estuary (Rudek et al. 1991), suggesting that the major differences between climatic regions, which determine the importance of nutrient storage and recycling to overall estuarine productivity, are also the timing and magnitude of hydrologic factors.

\section{Management implications}

The nutrient loading index developed in this study is similar to the susceptibility index of Anonymous $(1989 a, b)$ that was used to classify the susceptibility of estuaries in the USA to nutrient enrichment, and also the turnover-weighted loading rates suggested by Valiela \& Costa (1988) for assessing the relative impact of nutrient loadings in small coastal embayments. How- ever, the nutrient loading index differs from these 2 earlier approaches of Valiela \& Costa (1988) and Anonymous $(1989 \mathrm{a}, \mathrm{b})$ by including a seasonal component, and by separating diffuse and wastewater loads. The seasonal component and separation of diffuse and wastewater loads are important when examining the susceptibility of sub-tropical estuaries to nutrient enrichment and excess phytoplankton growth, because annual loads, particularly annual diffuse loads, are of little relevance when a large proportion ends up on the continental shelf (McKee et al. 2000).

The nutrient loading index also gives some guidelines for the loading rates that are necessary to achieve a given trophic status (chl a concentrations) in the 9 sub-tropical estuaries. However, the explanation of much of the variability in phytoplankton biomass in these 9 systems by a simple nutrient loading index contrasts with the findings of Pennock et al. (1994), who suggested that site-specific physical and biogeochemical processes should modify estuarine responses to nutrient enrichment. This can be explained by the consistency across the 9 estuaries of the other modifying factors listed by Pennock et al. (1994) (nutrient concentrations, turbidity, silicate availability, physical mixing); nutrient concentrations reflect nutrient loadings, none of the estuaries are light- or silicate-limited, and all the systems have a similar salinity structure. This suggests that the nutrient loading index developed in this study may be a useful management tool in other similar systems if an initial screening is undertaken to rule out other controlling factors such as light limitation, stratification and silicate limitation.

Because wastewater loadings appear to control chl a concentrations above a wastewater DIN loading index of 1, management strategies should firstly be directed at reducing wastewater DIN loadings to below a loading index of 1 . Although an arbitrary cut-off, a wastewater DIN loading index of $<1$ should also maintain mean and maximum chl a concentrations in the Tweed, Brunswick, Bellinger, Nambucca, Macleay and Hastings estuaries below the mean and maximum guideline concentrations of 4 and $10 \mu \mathrm{g} \mathrm{l}^{-1}$, respectively (Fig. 12), for maintaining high water quality in the lower reaches of sub-tropical Australian estuaries (Anonymous 1995). Once wastewater loadings are reduced, management strategies can then focus on controlling diffuse loadings. To achieve the same guideline chl a concentrations in the Richmond, Clarence and Manning, the diffuse DIN loading index would need to be reduced to below $\sim 20$.

There may however be a trade-off associated with reducing the wastewater loading index with a proportional reduction in fisheries production (Fig. 14). The normalised fisheries yield in most of the sub-tropical estuaries increases as the wastewater DIN loading 


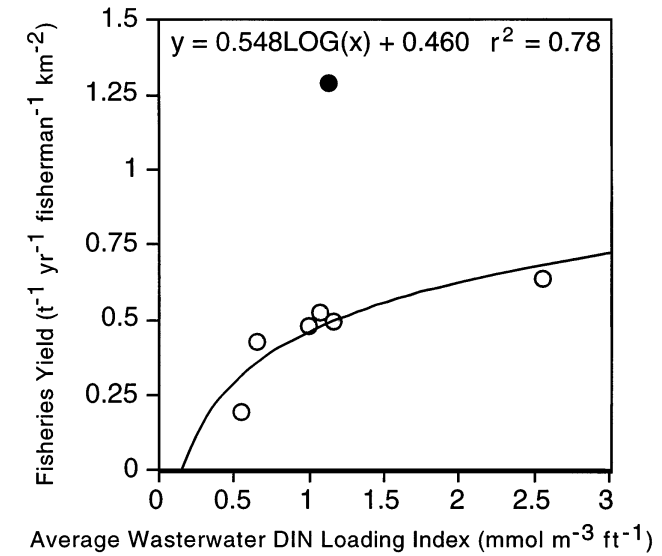

Fig. 14. Fisheries yield (New South Wales Fisheries) plotted as a function of wastewater DIN loading index for 7 of the sub-tropical estuaries studied. Fisheries yield data were not available for Brunswick or Richmond estuaries. Outlier (•, Nambucca Estuary) was excluded from regression analysis

index increases. Similar relationships between fisheries yield and primary production (Day et al. 1989) and fisheries yield and residence time-weighted nitrogen loading (Solis \& Powell 1999) have been found in other systems. The relationship in Fig. 14 suggests that most of the systems are currently not degraded to a point where fisheries yields decrease, although this gives no indication of other changes such as reduction in species diversity. However, it would not be expected that fisheries yield would continue to increase indefinitely as the wastewater DIN loading index increases. At some point, it would be expected that the systems would 'crash' and the fisheries yield would decline (Verity 1987, Pugnetti et al. 1992). Unfortunately, there were no fisheries yield data available for the Brunswick, which has a wasterwater loading index of 11 and is currently showing signs of degradation (Eyre 1997b). Further work is required to determine at what wastewater DIN loading index (critical level) the systems may 'crash'. It also needs to be established if the systems will return to a healthy state once the wastewater DIN loading index is reduced below a critical level, or if there is a hysteresis effect in the wastewater DIN loading index and fisheries yield relationship.

Acknowledgements. I would like to thank Peter Davies, who assisted with the estuary field work, undertook all of the laboratory work, and compiled the water-quality data base; without his professional support this study would not have been possible. Rick Southon and Graham Lancaster also helped with the estuary field work. Thanks also to the 9 catchment samplers. Peter Pepperell helped compile and analyse the data. Shadadat Hossain assisted with development of the mixing model. Angus Ferguson and David Nedwell reviewed early drafts of the manuscript. This study was funded by the NSW Government through an Environmental Research Trust Grant No. 95/RD/GO6.

\section{LITERATURE CITED}

Anonymous (1989a) Strategic assessment of near coastal waters. Susceptibility of east coast estuaries to nutrient discharge. Passamaquoddy Bay to Chesapeake Bay. Summary Report NOAA/EPA Team on Coastal Waters. NOAA/EPA Silver Spring, CO

Anonymous (1989b) Strategic assessment of near coastal waters. Susceptibility of Gulf of Mexico estuaries to nutrient discharge. Summary Report NOAA/EPA Team on Coastal Waters. NOAA/EPA Silver Spring, CO

Anonymous (1995) Explanatory notes for draft environmental protection (water) policy and draft Queensland water quality guidelines. Department of Environment and Heritage, Brisbane

Balls PW (1994) Nutrient inputs to estuaries from 9 Scottish east coast rivers; influence of estuarine processes on inputs to the North Sea. Estuar Coast Shelf Sci 39:329-352

Borum J (1996) Shallow waters and land/sea boundaries. In: Jørgensen BB, Richardson K (eds) Eutrophication in coastal marine systems. American Geophysical Union, Washington, DC, p 179-204

Boyle EA, Collier R, Dengler AT, Edmond JM, Ng AC, Stallard RF (1974) On the chemical mass balance in estuaries. Geochim Cosmochim Acta 14:35-54

Boynton WR, Kemp WM, Keefe CW (1982) A comparative analysis of nutrients and other factors influencing estuarine phytoplankton production. In: Kennedy VS (ed) Estuarine comparisons. Academic Press, New York, p 69-90

Bricker SB, Stevenson JC (1996) Nutrients in coastal waters: a chronology and synopsis of research. Estuaries 19: 337-341

Carlton RG, Wetzel RG (1988) Phosphorus flux from lake sediments: effect of epipelic algal oxygen production. Limnol Oceanogr 33:562-570

Christian RR, Boyer JN, Stanley DW (1991) Multi-year distribution patterns of nutrients within the Neuse River Estuary, North Carolina. Mar Ecol Prog Ser 71:259-274

Cifuentes LA, Schemel LE, Sharp JH (1990) Qualitative and numerical analysis of the effects of river inflow variations on mixing diagrams in estuaries. Estuar Coast Shelf Sci 30: $411-427$

Cloern JE (1996) Phytoplankton bloom dynamics in coastal ecosystems: a review with some general lessons from sustained investigation of San Francisco Bay, California. Rev Geophys 34:127-168

Cole BE, Cloern JE (1984) Significance of biomass and light availability to phytoplankton productivity in San Francisco Bay. Mar Ecol Prog Ser 17:15-24

Day JW Jr, Hall CAS, Kemp WM, Yanez-Arancibia A (1989) Estuarine ecology. John Wiley, New York

Dennison WC, Abal EG (1999) Moreton Bay study: a scientific basis for the healthy waterways campaign. South East Queensland regional Water Quality Management Strategy, Brisbane

Eyre BD (1995) A first-order nutrient budget for the tropical Moresby estuary and catchment North Queensland, Australia. J Coast Res 11:717-732

Eyre BD (1997a) Water quality changes in an episodically flushed sub-tropical Australian estuary: a 50 year perspective. Mar Chem 59:177-187

Eyre BD (1997b) Contribution of sewage effluent to the Brunswick Estuary nutrient budget. Report prepared for Byron Shire Council. Centre for Coastal Management, Lismore

Eyre BD (1998) Transport, retention and transformation of material in Australian estuaries. Estuaries 21:540-551

Eyre BD, Twigg C (1997) Nutrient behaviour during post- 
flood recovery of the Richmond River estuary northern NSW, Australia. Estuar Coast Shelf Sci 44:311-326

Eyre BD, Hossain S, McKee L (1998) A suspended sediment budget for the modified subtropical Brisbane river estuary, Australia. Estuar Coast Shelf Sci 47:513-522

Fisher TR, Harding LW Jr, Stanley DW, Ward LG (1988) Phytoplankton, nutrients and turbidity in the Chesapeake, Delaware and Hudson estuaries. Estuar Coast Shelf Sci 27: 61-93

Fisher TR, Peele ER, Ammerman JW, Harding LW (1992) Nutrient limitation of phytoplankton in Chesapeake Bay. Mar Ecol Prog Ser 82:51-63

Fisher TR, Melack JM, Grobbelaar JU, Howarth RW (1995) Nutrient limitation of phytoplankton and eutrophication of inland, estuarine, and marine waters. In: Tiessen H (ed) Phosphorus in the global cycle. John Wiley \& Sons, New York, p 301-322

Graneli E, Sundback K (1985) The response of phytoplankton and microbenthic algal assemblages to nutrient enrichment in shallow coastal waters, southwest Sweden. J Exp Mar Biol Ecol 85:253-268

Grobler JV (1985) Phytoplankton productivity in turbid waters. J Plankton Res 7:653-663

Harding LW Jr (1994) Long-term trends in the distribution of phytoplankton in Chesapeake Bay: roles of light, nutrients and streamflow. Mar Ecol Prog Ser 104:267-291

Harris G, Bately G, Jernakoff P, Newell B, Fox D, Molloy R, Parslow J, Walker S, Hall D, Murray A, Skyring G (1996) Port Phillip Bay environmental study. Final Report. Commonwealth Scientific and Industrial Research Organisation, Canberra

Hossain S (1997) Hydrology and suspended sediment transport in the Richmond River catchment and estuary, NSW Australia. PhD thesis, Southern Cross University, Lismore

Imberger J, Berman T, Christian RR, Sherr EB, Whitney DE, Pomeroy LR, Wiegert RG, Wiebe WJ (1983) The influence of water motion on the distribution and transport of materials in a salt marsh estuary. Limnol Oceanogr 28:201-214

Jørgensen BB, Richardson K (1996) Eutrophication in coastal marine ecosystems. American Geophysical Union, Washington, DC

Kaul LW, Froelich PN (1984) Modelling estuarine nutrient geochemistry in a simple system. Geochim Cosmochim Acta 48:1417-1433

Kemp WM, Boynton WR (1984) Spatial and temporal coupling of nutrient inputs to estuarine primary production: the role of particulate transport and decomposition. Bull Mar Sci 35:522-535

Kennish MJ (ed) (1986) Ecology of estuaries. CRC Press, Boca Raton, LA

Lachat (1994) International methods list for the QuikChem Automated Ion Analyzer. Lachat Instruments, Milwaukee

Lebo ME, Sharp JH, Cifuentes LA (1994) Contribution of river phosphate variations to apparent reactivity estimated from phosphate-salinity diagrams. Estuar Coast Shelf Sci 39:583-594

Loder TC, Reichard RP (1981) The dynamics of conservative mixing in estuaries. Estuaries 4:64-69

Malone TC (1992) Effects of water-column processes on dissolved oxygen: nutrients, phytoplankton and zooplankton. In: Smith D, Leffler M, Mackiernan G (eds) Oxygen dynamics in Chesapeake Bay: a synthesis of research. Maryland Sea Grant, College Park, MD, p 61-112

McKee L, Eyre BD, Hossain S (2000) Transport and retention of nitrogen and phosphorus in the sub-tropical Richmond River estuary - a budget approach. Biogeochemistry 50: 241-278

Editorial responsibility: John Austin (Assistant Editor), Oldendorf/Luhe, Germany
Nixon SW (1995) Coastal marine eutrophication: a definition, social causes, and future concerns. Ophelia 41:199-219

Norusis MJ (1994) SPSS professional statistics. Version 6.1. SPSS Inc, Chicago

O'Donohue MJH, Dennison WC (1997) Phytoplankton productivity response to nutrient concentrations, light availability and temperature along an Australian estuarine gradient. Estuaries 20:521-533

Officer CB (1979) Discussion of the behaviour of non-conservative dissolved constituents in estuaries. Estuar Coast Mar Sci 9:91-94

Officer CB, Lynch DR (1981) Dynamics of mixing in estuaries. Estuar Coast Shelf Sci 12:525-533

Pennock JR, Sharp JH, Schroeder WW (1994) What controls the expression of estuarine eutrophication? Case studies of nutrient enrichment in the Delaware Bay and Mobile Bay estuaries, USA. In: Dyer KR, Orth RJ (eds) Changes in fluxes in estuaries: implications from science to management. Olsen \& Olsen, Fredensborg, p 139-146

Pennock JR, Boyer JN, Herrera-Silveira JA, Iverson RI, Whitledge TE, Mortazavi B, Comin FA (1999) Nutrient behaviour and phytoplankton growth in Gulf of Mexico Estuaries. In: Bianchi TS, Pennock JR, Twilley RR (eds) Biogeochemistry of Gulf of Mexico Estuaries. John Wiley \& Sons, New York, p 109-162

Pugnetti A, Viaroli P, Ferrari M (1992) Processes leading to dystrophy in a Po River delta lagoon (Sacca di Goro): phytoplankton-macroalgae interactions. Sci Total Environ (Suppl) 6:445-456

Rudek J, Paerl HW, Mallin MA, Bates PW (1991) Seasonal and hydrological control of phytoplankton nutrient limitation in the lower Neuse River estuary, North Carolina. Mar Ecol Prog Ser 75:133-142

Seitzinger SP, Sanders RW (1997) Contribution of dissolved organic nitrogen from rivers to estuarine eutrophication. Mar Ecol Prog Ser 159:1-12

Sellner KG, Lacouture RV, Cibik SJ, Brindley A, Brownlee SG (1991) Importance of a winter dinoflagellate-microflagellate bloom in the Patuxent River Estuary. Estuar Coast Shelf Sci 32:27-42

Smith DE, Leffler M, Mackiernan G (1992) Oxygen dynamics in Chesapeake Bay. Maryland Sea Grant, College Park, MD

Solis RS, Powell GL (1999) Hydrography, mixing characteristics and residence times of Gulf of Mexico estuaries. In: Bianchi TS, Pennock JR, Twilley RR (eds) Biogeochemistry of Gulf of Mexico estuaries. John Wiley \& Sons, New York, p 29-61

Strickland JD, Parsons TR (1972) A practical handbook of seawater analysis, 2nd edn. Bull Fish Res Board Can 167

Treguer P, Queguiner B (1989) Seasonal variations in conservative and nonconservative mixing of nitrogen compounds in a West European macrotidal estuary. Oceanol Acta 12:371-380

Valderrama JC (1981) The simultaneous analysis of TP and TN in natural waters. Mar Chem 10:109-122

Valiela I (ed) (1995) Marine ecological processes, 2nd edn. Springer-Verlag, New York

Valiela I, Costa JE (1988) Eutrophication of Buttermilk Bay, a Cape Cod coastal embayment: concentrations of nutrients and watershed nutrient budgets. Environ Manag 12: 539-553

Verity PG (1987) Factors driving changes in the pelagic trophic structure of estuaries, with implications for the Chesapeake Bay. In: Lynch MP, Krome E (eds) Perspectives on the Chesapeake Bay. Chesapeake Bay Research Consortium, Baltimore, p 35-56 (CRC Publ 127)

Submitted: June 15, 1999; Accepted: February 10, 2000

Proofs received from author(s): October 2, 2000 